National Water Quality Program

National Water-Quality Assessment Project

\title{
Nutrient and Pesticide Contamination Bias Estimated From Field Blanks Collected at Surface-Water Sites in U.S. Geological Survey Water-Quality Networks, 2002-12
}

Scientific Investigations Report 2016-5129 



\section{Nutrient and Pesticide Contamination Bias Estimated From Field Blanks Collected at Surface-Water Sites in U.S. Geological Survey Water-Quality Networks, 2002-12}

By Laura Medalie and Jeffrey D. Martin

National Water Quality Program

National Water-Quality Assessment Project

Scientific Investigations Report 2016-5129 


\title{
U.S. Department of the Interior SALLY JEWELL, Secretary
}

\section{U.S. Geological Survey Suzette M. Kimball, Director}

\author{
U.S. Geological Survey, Reston, Virginia: 2016
}

For more information on the USGS - the Federal source for science about the Earth, its natural and living resources, natural hazards, and the environment—visit http://www.usgs.gov or call 1-888-ASK-USGS.

For an overview of USGS information products, including maps, imagery, and publications, visit http://store.usgs.gov.

Any use of trade, firm, or product names is for descriptive purposes only and does not imply endorsement by the U.S. Government.

Although this information product, for the most part, is in the public domain, it also may contain copyrighted materials as noted in the text. Permission to reproduce copyrighted items must be secured from the copyright owner.

Suggested citation:

Medalie, Laura, and Martin, J.D., 2016, Nutrient and pesticide contamination bias estimated from field blanks collected at surface-water sites in U.S. Geological Survey water-quality networks, 2002-12: U.S. Geological Survey Scientific Investigations Report 2016-5129, 40 p., https://doi.org/10.3133/sir20165129.

ISSN 2328-0328 (online) 


\section{Contents}

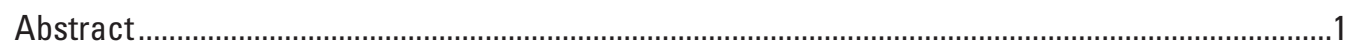

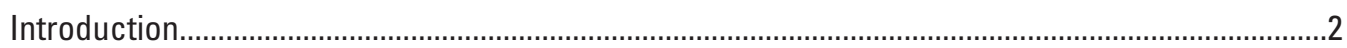

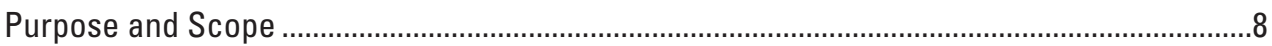

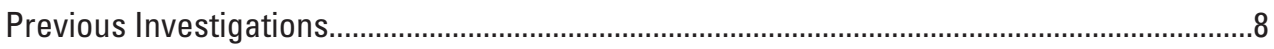

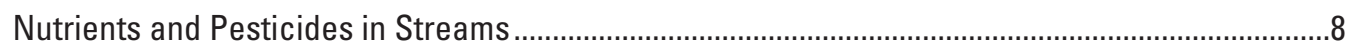

Data Collection and Analysis .............................................................................................

Procedures for the Collection of Field Blanks and Environmental Samples ...........................9

Laboratory Analytical Methods and Schedules ...................................................................

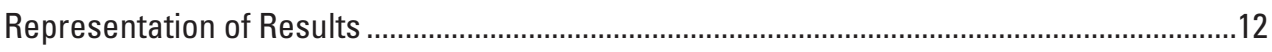

Data Retrieval, Processing, and Screening .................................................................... 13

Method Used to Determine Potential Contamination Bias....................................................14

Summary of Analytical Methods, Censoring, and Data From Field Blanks.......................................14

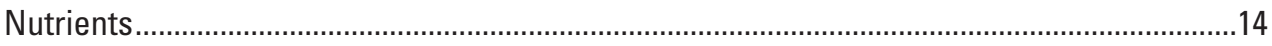

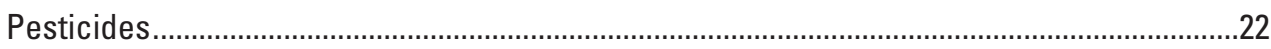

Assessment of Contamination and Implications for the Interpretation of

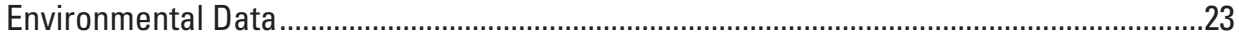

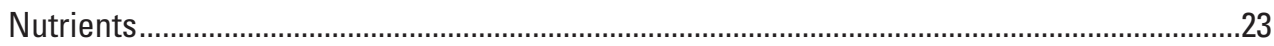

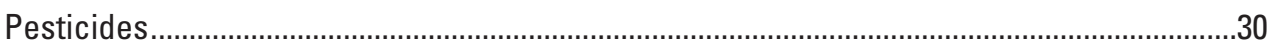

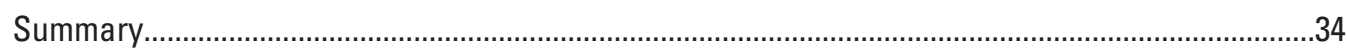

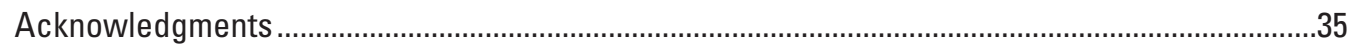

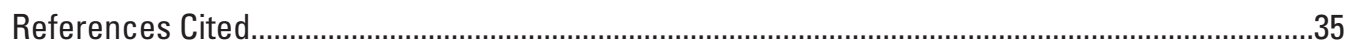

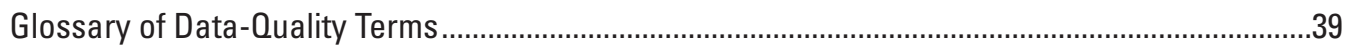

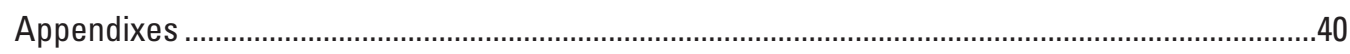

Appendix 1. Nutrient Field-Blank Data From Surface-Water Sites in Historical

U.S. Geological Survey Water-Quality Networks, 2002-12 ................................................40

Appendix 2. Pesticide Field-Blank Data From Surface-Water Sites in Historical

U.S. Geological Survey Water-Quality Networks, 2002-12 ...............................................40

\section{Figures}

1. Map showing locations of 147 surface-water-quality sample sites in historical U.S. Geological Survey water-quality networks, for which field-blank data for water years 2002-12 are presented in this report.

2. Time-series plots of concentrations, distinguished by analytical method, of ammonia, nitrite, nitrite plus nitrate, particulate nitrogen, total Kjeldahl nitrogen, total nitrogen, orthophosphate, and total phosphorus in field-blank and environmental surface-water samples from historical U.S. Geological Survey water-quality networks, water years 2002-12.

3. Graph showing distribution of nutrient analyte concentrations, split by analytical method and by date for some analytes, for field blanks associated with surface-water samples from historical U.S. Geological Survey water-quality networks, water years 2002-12. 
4. Graphs showing concentration summaries of ammonia, nitrite, nitrite plus nitrate, particulate nitrogen, total Kjeldahl nitrogen, total nitrogen, orthophosphate, and total phosphorus in field blanks associated with surface-water samples from historical U.S. Geological Survey water-quality networks, grouped by type of site, first two digits of site number, and sampling network, water years 2002-12..

5. Plots showing detections of metolachlor and atrazine in field blanks associated with surface-water samples from historical U.S. Geological Survey water-quality networks, grouped by type of site, first two digits of site number, sampling network, and National Water Quality Laboratory analytical schedule, water years 2002-12 ......22

6. Time-series plots of concentrations of dieldrin, metolachlor, atrazine, acetochlor, trifluralin, and Dacthal in field blanks associated with surface-water samples from historical U.S. Geological Survey water-quality networks, water years 2002-12 ...........25

7. Graphs showing distribution of concentrations of ammonia, nitrite, nitrite plus nitrate, particulate nitrogen, total Kjeldahl nitrogen, total nitrogen, orthophosphate, and total phosphorus in field-blank and environmental surface-water samples from historical U.S. Geological Survey water-quality networks, water years 2002-12 ..........28

8. Graphs showing distribution of concentrations of chlorpyrifos, dieldrin, metolachlor, atrazine, trifluralin, and Dacthal, in field blank and environmental surface-water samples from historical U.S. Geological Survey water-quality networks, water years 2002-12

\section{Tables}

1. List of 147 surface-water-quality sample sites in historical U.S. Geological Survey water-quality networks for which field-blank data for water years 2002-12 are analyzed in this report

2. National Water Quality Laboratory schedules and analytical methods with censor levels for nutrient analytes in surface-water samples from historical U.S. Geological Survey water-quality networks, water years 2002-12.

3. National Water Quality Laboratory schedules for pesticide analytes in surface-water samples from historical U.S. Geological Survey water-quality networks, water years 2002-12

4. Number and detection rates of field-blank and environmental samples and upper confidence limits for percent detections and concentrations in field blanks for selected percentiles, for nutrient analytes in surface-water samples from historical U.S. Geological Survey water-quality networks, water years 2002-12.

5. Number and detection rates of field-blank and environmental samples and 99-percent upper confidence limits for percent detections and concentrations in field blanks, for pesticides in surface-water samples from historical U.S. Geological Survey water-quality networks, water years 2002-12.

6. Potential contamination bias for environmental samples and critical or background values for relating to environmental samples.

7. Human-health and aquatic-life benchmarks for pesticides 


\section{Conversion Factors}

International System of Units to U.S. customary units

\begin{tabular}{lll}
\hline \multicolumn{1}{c}{ Multiply } & By & \multicolumn{1}{c}{ To obtain } \\
\hline liter (L) & Volume & gallon (gal) \\
milliliter (mL) & 0.2642 & ounce, fluid (fl. oz) \\
\hline
\end{tabular}

Temperature in degrees Celsius $\left({ }^{\circ} \mathrm{C}\right)$ may be converted to degrees Fahrenheit $\left({ }^{\circ} \mathrm{F}\right)$ as follows:

$$
{ }^{\circ} \mathrm{F}=\left(1.8 \times{ }^{\circ} \mathrm{C}\right)+32 \text {. }
$$

\section{Supplemental Information}

Concentrations of chemical constituents in water are given in milligrams per liter $(\mathrm{mg} / \mathrm{L})$ or micrograms per liter $(\mu \mathrm{g} / \mathrm{L})$.

A water year is the 12-month period October 1 through September 30 designated by the calendar year in which it ends.

\section{Abbreviations}

$\begin{array}{ll}\text { CWP } & \text { Cooperative Water Program } \\ \text { EPA } & \text { U.S. Environmental Protection Agency } \\ \text { GCMS } & \text { gas chromatography/mass spectrometry } \\ \text { HHB } & \text { human-health benchmark } \\ \text { LIMS } & \text { Laboratory Information Management System } \\ \text { LRL } & \text { laboratory reporting level } \\ \text { LTMDL } & \text { long-term method detection level } \\ \text { MCL } & \text { maximum contaminant level } \\ \text { NASQAN } & \text { National Stream Quality Accounting Network } \\ \text { NAWQA } & \text { National Water-Quality Assessment } \\ \text { NFM } & \text { National Field Manual for the Collection of Water-Quality Data } \\ \text { NMN } & \text { National Monitoring Network } \\ \text { NWIS } & \text { National Water Information System } \\ \text { NWOL } & \text { National Water Quality Laboratory } \\ \text { NWON } & \text { National Water Quality Network } \\ \text { NWOP } & \text { National Water Quality Program } \\ \text { PN } & \text { particulate nitrogen }\end{array}$




$\begin{array}{ll}\text { OA } & \text { quality assurance } \\ \text { OC } & \text { quality control } \\ \text { TKN } & \text { total Kjeldahl nitrogen } \\ \text { UCL } & \text { upper confidence limit } \\ \text { USGS } & \text { U.S. Geological Survey }\end{array}$




\title{
Nutrient and Pesticide Contamination Bias Estimated From Field Blanks Collected at Surface-Water Sites in U.S. Geological Survey Water-Quality Networks, 2002-12
}

\author{
By Laura Medalie and Jeffrey D. Martin
}

\section{Abstract}

Potential contamination bias was estimated for 8 nutrient analytes and 40 pesticides in stream water collected by the U.S. Geological Survey at 147 stream sites from across the United States, and representing a variety of hydrologic conditions and site types, for water years 2002-12. This study updates previous U.S. Geological Survey evaluations of potential contamination bias for nutrients and pesticides. Contamination is potentially introduced to water samples by exposure to airborne gases and particulates, from inadequate cleaning of sampling or analytic equipment, and from inadvertent sources during sample collection, field processing, shipment, and laboratory analysis. Potential contamination bias, based on frequency and magnitude of detections in field blanks, is used to determine whether or under what conditions environmental data might need to be qualified for the interpretation of results in the context of comparisons with background levels, drinking-water standards, aquatic-life criteria or benchmarks, or human-health benchmarks. Environmental samples for which contamination bias as determined in this report applies are those from historical U.S. Geological Survey water-quality networks or programs that were collected during the same time frame and according to the same protocols and that were analyzed in the same laboratory as field blanks described in this report.

Results from field blanks for ammonia, nitrite, nitrite plus nitrate, orthophosphate, and total phosphorus were partitioned by analytical method; results from the most commonly used analytical method for total phosphorus were further partitioned by date. Depending on the analytical method, 3.8, 9.2, or 26.9 percent of environmental samples, the last of these percentages pertaining to all results from 2007 through 2012, were potentially affected by ammonia contamination.

Nitrite contamination potentially affected up to 2.6 percent of environmental samples collected between 2002 and 2006 and affected about 3.3 percent of samples collected between 2007 and 2012. The percentages of environmental samples collected between 2002 and 2011 that were potentially affected by nitrite plus nitrate contamination were 7.3 for samples analyzed with the low-level method and 0.4 for samples analyzed with the standard-level method. These percentages increased to 14.8 and 2.2 for samples collected in 2012 and analyzed using replacement low- and standard-level methods, respectively. The maximum potentially affected concentrations for nitrite and for nitrite plus nitrate were much less than their respective maximum contamination levels for drinking-water standards. Although contamination from particulate nitrogen can potentially affect up to 21.2 percent and that from total Kjeldahl nitrogen can affect up to 16.5 percent of environmental samples, there are no critical or background levels for these substances.

For total nitrogen, orthophosphate, and total phosphorus, contamination in a small percentage of environmental samples might be consequential for comparisons relative to impairment risks or background levels. At the low ends of the respective ranges of impairment risk for these nutrients, contamination in up to 5 percent of stream samples could account for at least 23 percent of measured concentrations of total nitrogen, for at least 40 or 90 percent of concentrations of orthophosphate, depending on the analytical method, and for 31 to 76 percent of concentrations of total phosphorus, depending on the time period.

Twenty-six pesticides had no detections in field blanks. Atrazine with 12 and metolachlor with 11 had the highest number of detections, mostly occurring in spring or early summer. At a 99-percent level of confidence, contamination was estimated to be no greater than the detection limit in at least 98 percent of all samples for 38 of 40 pesticides. For metolachlor and atrazine, potential contamination was no greater than 0.0053 and 0.0093 micrograms per liter in 98 percent of samples. For 11 of 14 pesticides with at least one detection, the maximum potentially affected concentration of the environmental sample was less than their respective human-health or aquatic-life benchmarks. Small percentages of environmental samples had concentrations high enough that atrazine contamination potentially could account for the entire aquaticlife benchmark for acute effects on nonvascular plants, that dieldrin contamination could account for up to 100 percent of the cancer health-based screening level, or that chlorpyrifos contamination could account for 13 or 12 percent of the concentrations in the aquatic-life benchmarks for chronic effects on invertebrates or the criterion continuous concentration for chronic effects on aquatic life. 


\section{Introduction}

This report integrates quality-control ${ }^{1}$ (QC) information from selected surface-water sites monitored by the U.S. Geological Survey (USGS) from October 1, 2001, through September 30, 2012 (table 1 and fig. 1). The sampled sites operated under four different historical networks or programs during the report period. The majority of sites were incorporated into the USGS National Water Quality Network (NWQN) of the National Water Quality Program (NWQP) in 2015. The NWQP provides an understanding of water-quality conditions, whether conditions are getting better or worse over time, and how natural features and human activities affect those conditions (https://www.usgs.gov/science/mission-areas/ water/national-water-quality-program?qt-programs_12_landing_page=0\#qt-programs_12_landing_page).

The historical national networks or programs represented in this report are the USGS National Water-Quality Assessment (NAWQA) Project, the USGS National Stream Quality Accounting Network (NASQAN), the National Monitoring Network (NMN), and the USGS Cooperative Water Program (CWP). Not all sites from all four networks or programs are included in the site list of this report, but those included were active during and at the end of the report period. Hereafter, the sites included in this report are referred to as "historical USGS water-quality networks" (there is overlap but not an exact match with sites in the NWQN). Sites from NAWQA, started in 1991 to generate long-term and consistent information about the Nation's surface water, groundwater, and aquatic systems, are fixed sites at small to medium sized rivers sampled on a rotational basis (http://water.usgs.gov/nawqa/). This report includes some NAWQA sites that are not part of the NWQP. NASQAN sites are large rivers across the United States that provide annual data on loads of nutrients, sediment, and other water-quality constituents for large coastal estuaries and important tributaries in the Mississippi River Basin. NMN sites consist of a small number of annually sampled large river sites operated by the USGS that are part of a water-quality network designed by the National Water Quality Monitoring Council (http://acwi.gov/monitoring/network/). Some sites listed in table 1 as belonging to the NMN were sampled by other networks prior to NMN inception in 2008. The CWP, with streamgages in every State and built-in relevance to local and State issues, supports interpretive studies that are responsive to water science needs and emerging water issues (http:// water.usgs.gov/coop/about/). Some sites, such as the Potomac River at Chain Bridge at Washington, D.C., station number 01646580, were co-located for multiple networks (table 1) for at least part of the report period. This was typically done to leverage resources from a field crew that could collect different suites of analytes for multiple networks at important sites.

In addition to purpose, other important distinctions between historical USGS water-quality networks relate to drainage-area size and sampling protocols. Sites included in this report sampled by the CWP, NASQAN, and NMN are

\footnotetext{
${ }^{1}$ Terms listed in the glossary at the back of this report are in bold type where first used in the text.
}

generally large, and those sampled by NAWQA are generally small to medium (table 1). Sampling and field processing protocols of all USGS water-quality networks follow general guidelines in the USGS "National Field Manual for the Collection of Water-Quality Data" (NFM; U.S. Geological Survey, variously dated), but before the advent of the NWQP, consistency between networks was not a USGS goal. For example, a major difference between networks during the report period that might have a bearing on the determination of contamination bias, pertaining both to nutrients and pesticides, was specification of the suite (schedule) of chemical constituents analyzed. In addition, the selection of analytical method for certain nutrient analytes differed among networks.

A protocol in the NFM that generally was followed by all USGS sampling programs was the collection and analysis of QC samples along with environmental samples. The goal of QC sampling is to identify, quantify, and document bias and variability in data that result from the collection, processing, shipping, handling, and analysis of samples. Blank samples are a type of QC sample collected along with environmental water to determine the extent to which bias might affect interpretation of the environmental data. Bias and variability affect the accuracy of environmental samples. A blank sample is intended to be free of the compounds of interest. Contamination is indicated when a compound of interest is detected in a blank sample. Blank samples are used to test for contamination that can be introduced by exposure to airborne gases and particulates, from inadequately cleaned sampling or analytic equipment, or from inadvertent sources during sample collection, field processing, shipment, and laboratory analysis. Contamination typically produces a consistently positive (systematic) bias in the analytical results that may need to be considered in subsequent analysis and interpretation of the environmental data (Martin and others, 1999).

Field-blank water samples are a specific type of blank sample used to demonstrate that the equipment has been adequately cleaned to remove contamination introduced from a previous site or during transport of equipment, that sample collection and processing have not resulted in contamination, and that sample shipping and laboratory analysis have not introduced contamination. Field blanks are prepared and processed in the field in the same location as, but prior to, environmental water sample collection (Mueller and others, 1997). The reasoning is that potential exposure to contamination in the field is the same for field blanks as for associated environmental samples and that the frequency and magnitude of contamination are similar for field blanks and environmental samples (Mueller and others, 2015). Guidelines in the USGS NFM (U.S. Geological Survey, variously dated) indicate that field blanks are to be (1) collected routinely during the period of environmental sampling; (2) collected during periods when contamination is most probable, such as after field equipment has been in contact with high concentrations of contaminants of interest or during the seasons of high usage; and (3) distributed among sites to assess a broad range of locations, hydrologic conditions, and water types (U.S. Geological Survey, variously dated; Martin and others, 1999). 
Table 1. List of 147 surface-water-quality sample sites in historical U.S. Geological Survey water-quality networks for which fieldblank data for water years 2002-12 are analyzed in this report. The majority of sites were consolidated into the U.S. Geological Survey National Water Quality Network (NWQN) in 2015. Site locations are shown in figure 1.

[An * in the "Network" column means that the site is part of the National Water Quality Network. Two pairs of sites have the same site numbers, as identified and explained in footnotes. Site locations are shown in figure 1. States are identified by U.S. Postal Service abbreviations. USGS, U.S. Geological Survey; Mt. Mount; Hwy, Highway; St., Saint, NIB, northerly international boundary; Ft, Fort; NAWQA, National Water-Quality Assessment Project; NMN, National Monitoring Network; NASQAN, National Stream Quality Accounting Network; CWP, Cooperative Water Program; --, no data]

\begin{tabular}{|c|c|c|c|c|}
\hline $\begin{array}{c}\text { Site } \\
\text { number } \\
\text { (fig. 1) }\end{array}$ & USGS station number & Site name & Network $^{1}$ & $\begin{array}{c}\text { Drainage area, } \\
\text { in square } \\
\text { miles }\end{array}$ \\
\hline 1 & 01104615 & Charles River near Watertown, MA & NAWQA & 268 \\
\hline 2 & 01170100 & Green River near Colrain, MA & NAWQA* & 41 \\
\hline 3 & 01184000 & Connecticut River at Thompsonville, CT & NAWQA* & 9,660 \\
\hline 4 & 01209710 & Norwalk River at Winnipauk, CT & NAWQA* & 33 \\
\hline 5 & 01349150 & Canajoharie Creek near Canajoharie, NY & NAWQA* & 60 \\
\hline 6 & 01356190 & Lisha Kill northwest of Niskayuna, NY & NAWQA & 15 \\
\hline 7 & 01357500 & Mohawk River at Cohoes, NY & NAWQA & 3,519 \\
\hline 8 & $01372043^{2}$ & Hudson River near Poughkeepsie, NY & NMN* & 11,700 \\
\hline 8 & $01372058^{2}$ & Hudson River below Poughkeepsie, NY & $\mathrm{NMN}^{*}$ & 11,740 \\
\hline 9 & 01403300 & Raritan River at Bound Brook, NJ & NAWQA & 801 \\
\hline 10 & 01403900 & Bound Brook at Middlesex, NJ & NAWQA & 49 \\
\hline 11 & 01463500 & Delaware River at Trenton, NJ & $\mathrm{NMN}^{*}$ & 6,780 \\
\hline 12 & 01464907 & Little Neshaminy Creek near Warminster, PA & NAWQA & 28 \\
\hline 13 & 01472157 & French Creek near Phoenixville, PA & NAWQA & 59 \\
\hline 14 & 01578310 & Susquehanna River at Conowingo, MD & NASQAN* & 27,100 \\
\hline 15 & 01610400 & Waites Run near Wardensville, WV & NAWQA* & 13 \\
\hline 16 & 01621050 & Muddy Creek at Mount Clinton, VA & NAWQA & 14 \\
\hline 17 & 01646580 & Potomac River at Chain Bridge at Washington, DC & NASQAN, NAWQA* & 11,570 \\
\hline 18 & 01654000 & Accotink Creek near Annandale, VA & NAWQA* & 24 \\
\hline 19 & 02084160 & Chicod Creek near Simpson, NC & NAWQA & 14 \\
\hline 20 & 02087580 & Swift Creek near Apex, NC & NAWQA* & 21 \\
\hline 21 & 02089500 & Neuse River at Kinston, $\mathrm{NC}$ & NAWQA* & 2,692 \\
\hline 22 & 02091500 & Contentnea Creek at Hookerton, $\mathrm{NC}$ & NAWQA* & 733 \\
\hline 23 & 02169570 & Gills Creek at Columbia, SC & NAWQA & 60 \\
\hline 24 & 02172300 & McTier Creek near Monetta, SC & NAWQA* & 16 \\
\hline 25 & 02174250 & Cow Castle Creek near Bowman, SC & NAWQA & 24 \\
\hline 26 & 02175000 & Edisto River near Givhans, SC & NAWQA* & 2,730 \\
\hline 27 & 02226160 & Altamaha River at Everett City, GA & NASQAN* & 14,000 \\
\hline 28 & 02281200 & Hillsboro Canal near Shawano, FL & NAWQA & 311 \\
\hline 29 & 02306774 & Rocky Creek near Citrus Park, FL & NAWQA & 18 \\
\hline 30 & 02317797 & Little River near Tifton, GA & NAWQA & 129 \\
\hline 31 & 02318500 & Withlacoochee River near Quitman, GA & NAWQA & 1,492 \\
\hline 32 & 02335870 & Sope Creek near Marietta, GA & NAWQA* & 31 \\
\hline 33 & 02338000 & Chattahoochee River near Whitesburg, GA & NAWQA* & 2,430 \\
\hline 34 & 02338523 & Hillibahatchee Creek near Franklin, GA & NAWQA* & 17 \\
\hline 35 & 02350080 & Lime Creek near Cobb, GA & NAWQA & 62 \\
\hline 36 & 02359170 & Apalachicola River near Sumatra, FL & NMN* & 19,200 \\
\hline 37 & 0242354750 & Cahaba Valley Creek at Pelham, AL & NAWQA & 25 \\
\hline 38 & 02424000 & Cahaba River at Centreville, AL & NAWQA & 1,027 \\
\hline
\end{tabular}


Table 1. List of 147 surface-water-quality sample sites in historical U.S. Geological Survey water-quality networks for which fieldblank data for water years 2002-12 are analyzed in this report. The majority of sites were consolidated into the U.S. Geological Survey National Water Quality Network (NWON) in 2015. Site locations are shown in figure 1.-Continued

[An * in the "Network" column means that the site is part of the National Water Quality Network. Two pairs of sites have the same site numbers, as identified and explained in footnotes. Site locations are shown in figure 1. States are identified by U.S. Postal Service abbreviations. USGS, U.S. Geological Survey; Mt. Mount; Hwy, Highway; St., Saint, NIB, northerly international boundary; Ft, Fort; NAWQA, National Water-Quality Assessment Project; NMN, National Monitoring Network; NASQAN, National Stream Quality Accounting Network; CWP, Cooperative Water Program; --, no data]

\begin{tabular}{|c|c|c|c|c|}
\hline $\begin{array}{l}\text { Site } \\
\text { number } \\
\text { (fig. 1) }\end{array}$ & USGS station number & Site name & Network $^{1}$ & $\begin{array}{c}\text { Drainage area, } \\
\text { in square } \\
\text { miles }\end{array}$ \\
\hline 39 & 02469762 & Tombigbee River near Coffeeville, AL & NAWQA* & 18,417 \\
\hline 40 & 02470500 & Mobile River at Mt. Vernon, AL & NASQAN* & 42,867 \\
\hline 41 & 03086000 & Ohio River at Sewickley, PA & CWP & 19,500 \\
\hline 42 & 03267900 & Mad River near Eagle City, OH & NAWQA & 310 \\
\hline 43 & 03303280 & Ohio River at Cannelton Dam at Cannelton, IN & NASQAN* & 97,000 \\
\hline 44 & 03357330 & Big Walnut Creek near Roachdale, IN & NAWQA & 310 \\
\hline 45 & 03374100 & White River at Hazleton, IN & NASQAN, NAWQA* & 11,305 \\
\hline 46 & 03378500 & Wabash River at New Harmony, IN & NASQAN* & 29,234 \\
\hline 47 & 03466208 & Big Limestone Creek near Limestone, TN & NAWQA & 79 \\
\hline 48 & 03467609 & Nolichucky River near Lowland, TN & NAWQA & 1,688 \\
\hline 49 & 0357479650 & Hester Creek near Plevna, AL & NAWQA & 29 \\
\hline 50 & 03575100 & Flint River near Brownsboro, AL & NAWQA & 374 \\
\hline 51 & 03609750 & Tennessee River at Hwy 60 near Paucah, KY & NASQAN* & 40,330 \\
\hline 52 & 03612500 & Ohio River at Dam 53 near Grand Chain, IL & NASQAN* & 203,100 \\
\hline 53 & 04063700 & Popple River near Fence, WI & NAWQA* & 139 \\
\hline 54 & 04072050 & Duck Creek near Oneida, WI & NAWQA & 95 \\
\hline 55 & 040869415 & Lincoln Creek at Milwaukee, WI & NAWQA & 13 \\
\hline 56 & 04161820 & Clinton River at Sterling Heights, MI & NAWQA* & 309 \\
\hline 57 & 04175600 & River Raisin near Manchester, MI & NAWQA & 132 \\
\hline 58 & 04186500 & Auglaize River near Fort Jennings, OH & NAWQA & 331 \\
\hline 59 & 04193500 & Maumee River at Waterville, $\mathrm{OH}$ & NAWQA* & 6,330 \\
\hline 60 & 04264331 & St. Lawrence River at Cornwall, Ontario near Massena, NY & NASQAN* & 298,800 \\
\hline 61 & 05288705 & Shingle Creek at Minneapolis, MN & NAWQA* & 28 \\
\hline 62 & 05320270 & Little Cobb River near Beauford, MN & NAWQA & 130 \\
\hline 63 & 05331580 & Mississippi River at Hastings, MN & NAWQA* & 37,100 \\
\hline 64 & 05420500 & Mississippi River at Clinton, IA & NASQAN* & 85,600 \\
\hline 65 & 05420680 & Wapsipinicon River near Tripoli, IA & NAWQA & 346 \\
\hline 66 & 05451210 & South Fork Iowa River near New Providence, IA & NAWQA* & 224 \\
\hline 67 & 05465500 & Iowa River at Wapello, IA & NAWQA* & 12,500 \\
\hline 68 & 05490500 & Des Moines River at Keosauqua, IA & NAWQA* & 14,038 \\
\hline 69 & 05531500 & Salt Creek at Western Springs, IL & NAWQA & 37,049 \\
\hline 70 & 05532500 & Des Plaines River at Riverside, IL & NAWQA & 634 \\
\hline 71 & 05572000 & Sangamon River at Monticello, IL & NAWQA & 551 \\
\hline 72 & 05586100 & Illinois River at Valley City, IL & NASQAN, NAWQA* & 26,743 \\
\hline 73 & 05587455 & Mississippi River below Grafton, IL & NASQAN* & 171,300 \\
\hline 74 & 06279500 & Bighorn River near Kane, WY & NAWQA & 15,762 \\
\hline 75 & 06295000 & Yellowstone River at Forsyth, MT & NAWQA & 39,456 \\
\hline 76 & 06324970 & Little Powder River near Weston, WY & NAWQA* & 1,237 \\
\hline 77 & 06329500 & Yellowstone River near Sidney, MT & NAWQA* & 68,394 \\
\hline
\end{tabular}


Table 1. List of 147 surface-water-quality sample sites in historical U.S. Geological Survey water-quality networks for which fieldblank data for water years 2002-12 are analyzed in this report. The majority of sites were consolidated into the U.S. Geological Survey National Water Quality Network (NWQN) in 2015. Site locations are shown in figure 1.-Continued

[An * in the "Network" column means that the site is part of the National Water Quality Network. Two pairs of sites have the same site numbers, as identified and explained in footnotes. Site locations are shown in figure 1. States are identified by U.S. Postal Service abbreviations. USGS, U.S. Geological Survey; Mt. Mount; Hwy, Highway; St., Saint, NIB, northerly international boundary; Ft, Fort; NAWQA, National Water-Quality Assessment Project; NMN, National Monitoring Network; NASQAN, National Stream Quality Accounting Network; CWP, Cooperative Water Program; --, no data]

\begin{tabular}{|c|c|c|c|c|}
\hline $\begin{array}{c}\text { Site } \\
\text { number } \\
\text { (fig. 1) }\end{array}$ & USGS station number & Site name & Network $^{1}$ & $\begin{array}{c}\text { Drainage area, } \\
\text { in square } \\
\text { miles }\end{array}$ \\
\hline 78 & 06610000 & Missouri River at Omaha, NE & NASQAN* & 322,800 \\
\hline 79 & 06713500 & Cherry Creek at Denver, CO & NAWQA* & 24 \\
\hline 80 & 06754000 & South Platte River near Kersey, CO & NAWQA* & 9,708 \\
\hline 81 & 06795500 & Shell Creek near Columbus, NE & NAWQA & 294 \\
\hline 82 & 06800000 & Maple Creek near Nickerson, NE & NAWQA* & 369 \\
\hline 83 & 06800500 & Elkhorn River at Waterloo, NE & NAWQA* & 6,946 \\
\hline 84 & 06805500 & Platte River at Louisville, NE & NASQAN, NAWQA* & 85,520 \\
\hline 85 & 06902000 & Grand River near Sumner, MO & CWP & 6,880 \\
\hline 86 & 06926510 & Osage River near St. Thomas, MO & CWP & 14,584 \\
\hline 87 & 06934500 & Missouri River at Hermann, MO & NASQAN* & 522,500 \\
\hline 88 & 07022000 & Mississippi River at Thebes, IL & NASQAN* & 713,200 \\
\hline 89 & $07050500^{3}$ & Kings Creek near Berryville, AR & NAWQA & 527 \\
\hline 90 & 07053250 & Yocum Creek near Oak Grove, AR & NAWQA & 53 \\
\hline 91 & 07055646 & Buffalo River near Boxley, AR & NAWQA* & 59 \\
\hline 92 & 07060710 & North Sylamore Creek near Fifty Six, AR & NAWQA* & 58 \\
\hline 93 & $07189000^{3}$ & Elk River near Tiff City, MO & NAWQA & 851 \\
\hline 94 & 07241550 & North Canadian River near Harrah, OK & NAWQA & 13,775 \\
\hline 95 & 07263620 & Arkansas River Terry Lock \& Dam below Little Rock, AR & NASQAN* & 158,429 \\
\hline 96 & 07288955 & Yazoo River below Steele Bayou near Long Lake, MS & NASQAN, NAWQA* & 13,476 \\
\hline 97 & 07373420 & Mississippi River at St. Francisville, LA & NASQAN* & $1,125,300$ \\
\hline 98 & 07374000 & Mississippi River at Baton Rouge, LA & NASQAN* & $1,125,810$ \\
\hline 99 & 07374525 & Mississippi River at Belle Chasse, LA & NASQAN* & $1,130,000$ \\
\hline 100 & 07375050 & Tchefuncte River near Covington, LA & NAWQA & 145 \\
\hline 101 & 07379960 & Dawson Creek at Baton Rouge, LA & NAWQA & 37 \\
\hline 102 & 07381495 & Atchafalaya River at Melville, LA & NASQAN* & 93,316 \\
\hline 103 & 07381590 & Wax Lake Outlet at Calumet, LA & NASQAN* & -- \\
\hline 104 & 07381600 & Lower Atchafalaya River at Morgan City, LA & NASQAN & -- \\
\hline 105 & 08012150 & Mermentau River at Mermentau, LA & NAWQA & 1,381 \\
\hline 106 & 08014500 & Ouiska Chitto Creek near Oberlin, LA & NAWQA* & 504 \\
\hline 107 & 08051500 & Clear Creek near Sanger, TX & NAWQA & 303 \\
\hline 108 & 08057200 & White Rock Creek at Dallas, TX & NAWQA* & 67 \\
\hline 109 & 08057410 & Trinity River below Dallas, TX & NAWQA* & 6,283 \\
\hline 110 & 08116650 & Brazos River near Rosharon, TX & $\mathrm{NMN}^{*}$ & 45,339 \\
\hline 111 & 08178800 & Salado Creek at San Antonio, TX & NAWQA & 195 \\
\hline 112 & 08364000 & Rio Grande at El Paso, TX & NAWQA* & 29,945 \\
\hline 113 & 08475000 & Rio Grande near Brownsville, TX & NASQAN* & 176,333 \\
\hline 114 & 09163500 & Colorado River near Colorado-Utah State line & NAWQA* & 17,849 \\
\hline 115 & 094196783 & Las Vegas Wash near Las Vegas, NV & NAWQA & 1,019 \\
\hline 116 & 09471000 & San Pedro River at Charleston, AZ & NAWQA* & 1,257 \\
\hline
\end{tabular}


Table 1. List of 147 surface-water-quality sample sites in historical U.S. Geological Survey water-quality networks for which fieldblank data for water years 2002-12 are analyzed in this report. The majority of sites were consolidated into the U.S. Geological Survey National Water Quality Network (NWQN) in 2015. Site locations are shown in figure 1.-Continued

[An * in the "Network" column means that the site is part of the National Water Quality Network. Two pairs of sites have the same site numbers, as identified and explained in footnotes. Site locations are shown in figure 1. States are identified by U.S. Postal Service abbreviations. USGS, U.S. Geological Survey; Mt. Mount; Hwy, Highway; St., Saint, NIB, northerly international boundary; Ft, Fort; NAWQA, National Water-Quality Assessment Project; NMN, National Monitoring Network; NASQAN, National Stream Quality Accounting Network; CWP, Cooperative Water Program; --, no data]

\begin{tabular}{|c|c|c|c|c|}
\hline $\begin{array}{c}\text { Site } \\
\text { number } \\
\text { (fig. 1) }\end{array}$ & USGS station number & Site name & Network $^{1}$ & $\begin{array}{c}\text { Drainage area, } \\
\text { in square } \\
\text { miles }\end{array}$ \\
\hline 117 & 09481740 & Santa Cruz River at Tubac, AZ & NAWQA & 1,210 \\
\hline 118 & 09505800 & West Clear Creek near Camp Verde, AZ & NAWQA* & 237 \\
\hline 119 & 09517000 & Hassayampa River near Arlington, AZ & NAWQA & 1,471 \\
\hline 120 & 09522000 & Colorado River at NIB, above Morelos Dam, AZ & NASQAN* & 246,700 \\
\hline 121 & 10168000 & Little Cottonwood Creek at Salt Lake City, UT & NAWQA* & 45 \\
\hline 122 & 10171000 & Jordan River at Salt Lake City, UT & NAWQA* & 3,511 \\
\hline 123 & 10172200 & Red Butte Creek at Ft Douglas, UT & NAWQA* & 7 \\
\hline 124 & 10311400 & Carson River at Deer Run Rd near Carson City, NV & NAWQA & 958 \\
\hline 125 & $10350340^{4}$ & Truckee River at Tracy, NV & NAWQA* & 1,580 \\
\hline 125 & $10350500^{4}$ & Truckee River at Clark, NV & NAWQA* & 1,592 \\
\hline 126 & 11074000 & Santa Ana River below Prado Dam, CA & NAWQA* & 1,473 \\
\hline 127 & 11273500 & Merced River near Newman, CA & NAWQA & 1,397 \\
\hline 128 & 11274538 & Orestimba Creek near Crows Landing, CA & NAWQA* & 11 \\
\hline 129 & 11303500 & San Joaquin River near Vernalis, CA & NASQAN, NAWQA* & 7,345 \\
\hline 130 & 11447360 & Arcade Creek near Del Paso Heights, CA & NAWQA & 31 \\
\hline 131 & 11447650 & Sacramento River at Freeport, CA & NASQAN, NAWQA* & 23,830 \\
\hline 132 & 12128000 & Thornton Creek near Seattle, WA & NAWQA & 11 \\
\hline 133 & 12464770 & Crab Creek near Ritzville, WA & NAWQA & 459 \\
\hline 134 & 12505450 & Granger Drain at Granger, WA & NAWQA* & 63 \\
\hline 135 & 12510500 & Yakima River at Kiona, WA & NAWQA* & 6,023 \\
\hline 136 & 13055000 & Teton River near St. Anthony, ID & NAWQA & 876 \\
\hline 137 & 13056500 & Henrys Fork near Rexburg, ID & NAWQA* & 2,920 \\
\hline 138 & 13092747 & Rock Creek at Twin Falls, ID & NAWQA* & 241 \\
\hline 139 & 13154500 & Snake River at King Hill, ID & NAWQA* & 35,885 \\
\hline 140 & 14201300 & Zollner Creek near Mt. Angel, OR & NAWQA* & 15 \\
\hline 141 & 14205400 & East Fork Dairy Creek near Meachan Corner, OR & NAWQA* & 33 \\
\hline 142 & 14206950 & Fanno Creek at Durham, OR & NAWQA* & 31 \\
\hline 143 & 14211720 & Willamette River at Portland, OR & NAWQA* & 11,173 \\
\hline 144 & 14246900 & Columbia River near Beaver Army Terminal, OR & NASQAN* & 256,900 \\
\hline 145 & 15565447 & Yukon River at Pilot Station, AK & NASQAN* & 321,000 \\
\hline 146 & $322023090544500^{5}$ & Mississippi River at Mile 438 (above Vicksburg, MS) & $\mathrm{NMN}^{*}$ & $1,131,100$ \\
\hline 147 & $394340085524601^{6}$ & Sugar Creek at New Palestine, IN & NAWQA* & 93 \\
\hline
\end{tabular}

${ }^{1}$ All stations listed as NASQAN and NMN, and some of the NAWQA stations, are part of the National Water Quality Network.

${ }^{2} \mathrm{NMN}$ station 01372058 was replaced in the network by station 01372043 on October 1, 2009.

${ }^{3}$ NAWQA station 07050500 was replaced in the network by station 07189000 on October 1, 2008.

${ }^{4}$ NAWQA station 10350500 was replaced in the network by station 10350340 on October 1, 2010.

${ }^{5}$ Streamflows associated with this water-quality station are measured at station 07289000, Mississippi River at Vicksburg, MS.

${ }^{6}$ Streamflows associated with this water-quality station are measured at station 03361650, Sugar Creek at New Palestine, IN. 


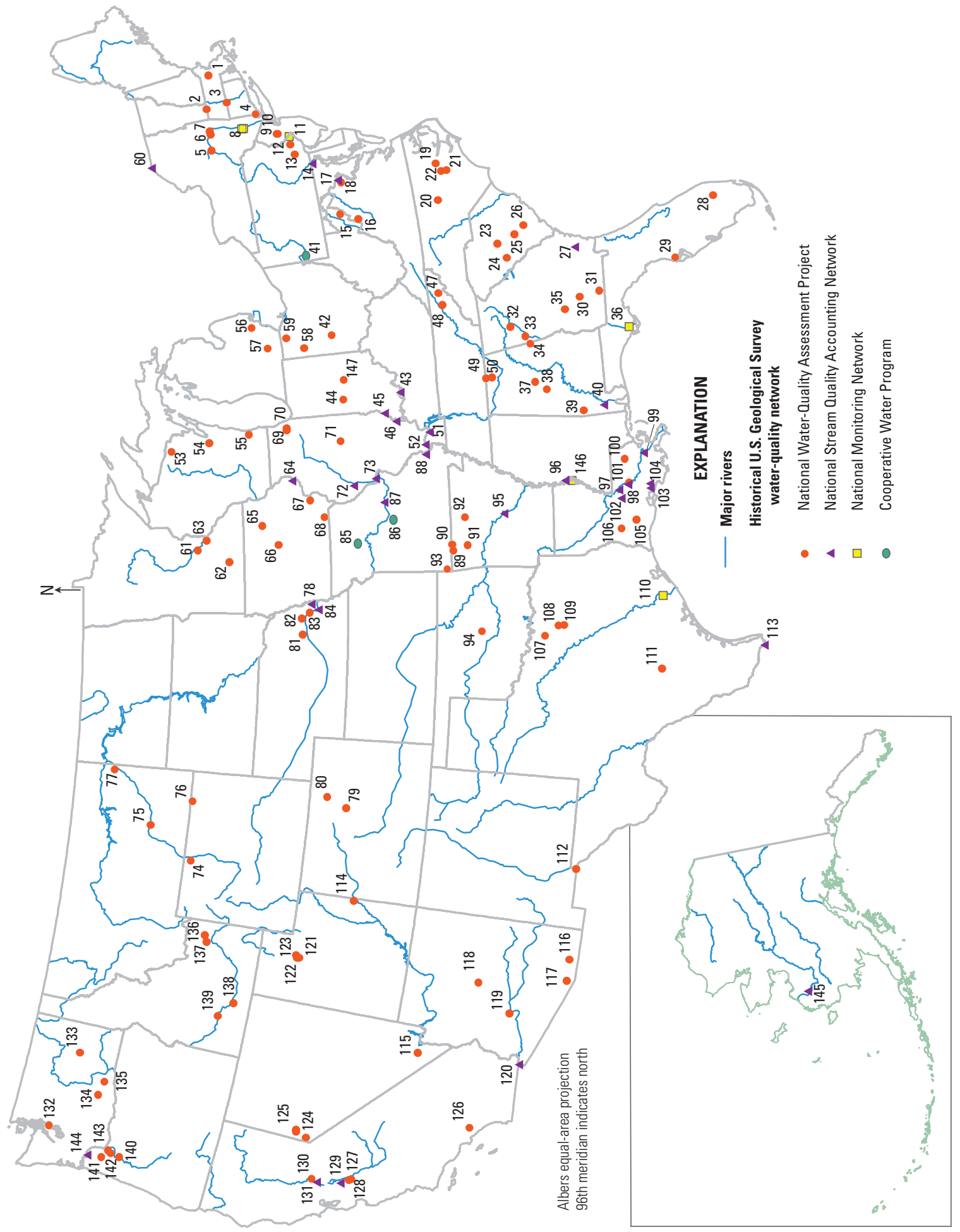

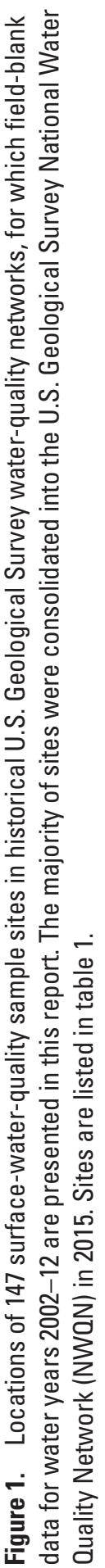




\section{Purpose and Scope}

The purpose of this report is to describe the quality of data, based on a summary and analysis of contamination bias, for 8 nutrient analytes and 40 pesticide concentrations in stream-water samples collected at 147 sites in historical USGS water-quality networks during water years ${ }^{2} 2002-12$ (table 1 and fig. 1). This report updates previous USGS evaluations of potential contamination bias of nutrients from 1992-2001 and pesticides from 1992-1995 (Mueller and Titus, 2005; Martin and others, 1999), while expanding the list of surface-water sites and refining the constituent list for relevancy. All sites had field-blank data collected during, as well as near the end of, the study period. The range of years corresponds to cycle 2 (October 1, 2001, through September 30, 2012) of NAWQA. ${ }^{3}$ Sites providing the QC data represent a broad array of hydrologic conditions and watershed characteristics in the 48 contiguous States and Alaska. This report presents the nutrients and pesticides investigated and describes the methods of collecting and processing samples, analyzing samples in the laboratory, censoring results, retrieving and processing data, and determining potential contamination bias. The results of this QC analysis are compared to characteristics of the environmental data and either to background levels, drinking-water standards, or aquatic-life criteria (for nutrients), or to human-health and aquatic-life benchmarks or aquatic-life criteria (for pesticides), to assess the potential effects of contamination bias on interpretation of environmental data.

A secondary purpose is to provide an accessible dataset of concentrations of field blanks from historical USGS waterquality networks associated with surface-water samples for cycle 2 nutrients (appendix 1) and pesticides (appendix 2).

\section{Previous Investigations}

Several USGS reports on water quality describe using routine field-blank results to assess contamination in environmental data. An evaluation of contamination bias for five nutrient analytes sampled at NAWQA surface-water sites from 1992 to 2001 concluded that ammonia and, to a lesser extent, orthophosphate contamination could affect environmental results in the low range of concentrations (Mueller and Titus, 2005). An assessment of field-blank results for pesticides from 1992-95 indicated that although bias contamination did not need to be considered for most pesticide data collected from surface water, it should be taken into consideration in calculating detection frequencies for 7 pesticides and median concentrations for 5 pesticides (Martin and others, 1999). Toccalino and others (2010) and DeSimone (2009) describe using findings from Mueller and Titus (2005) and Martin and others

\footnotetext{
${ }^{2} \mathrm{~A}$ water year is the 12 -month period October 1 through September 30 designated by the calendar year in which it ends.

${ }^{3}$ Organized temporally into cycles by water year, NAWQA cycle 1 samples were collected during 1991-2001, NAWQA cycle 2 samples during 2002-12, and NAWQA cycle 3 samples beginning in 2013.
}

(1999) to corroborate (or exclude if affected by contamination) environmental data. Sprague and others (2007) determined that isolated, low-level contamination of total ammonia plus organic (Kjeldahl) nitrogen contamination in field blanks did not substantially affect results of stream chemistry during base flow across the United States during 2002-4. All of these studies were conducted as part of NAWQA.

\section{Nutrients and Pesticides in Streams}

Nutrients are chemical compounds of nitrogen and phosphorus that are necessary to plant and animal life in limited quantities. High concentrations of nutrients can contaminate water and lead to impairment of aesthetic and recreational quality, human or animal health, ecosystem function, and certain infrastructure performance (Dubrovsky and others, 2010). Nutrient forms cycle between water, soil, biota, and the atmosphere via chemical and biological processes. Nutrient analytes discussed in this report are expressed as concentrations of nitrogen or phosphorus (as $\mathrm{N}$ or as $\mathrm{P}$ ).

Six nitrogen analytes were investigated. The selection of distinct combinations of analytes and analytical methods by different networks is discussed in greater detail in the "Summary of Analytical Methods, Censoring, and Data From Field Blanks" section. Three analytes (ammonia, nitrite, and nitrite plus nitrate) were measured in their dissolved forms in filtered samples. Ammonia is a compound of nitrogen and hydrogen; its un-ionized form is toxic to fish. Nitrite and nitrate are compounds of nitrogen and oxygen. Nitrate is highly soluble in water, is stable over a wide range of environmental conditions, and is the primary form of dissolved nitrogen in natural water. Total Kjeldahl nitrogen (TKN, parameter code 625), used widely by the National Water Quality Laboratory (NWQL) until 2003, analyzes for ammonia after the Kjeldahl digestion process reduces organic nitrogen species to ammonia. For unfiltered samples, TKN equals the sum of ammonia plus organic nitrogen in the dissolved and particulate phases. In 2003, the NWQL introduced a total nitrogen (parameter code 62855) method that analyzes for nitrate after oxidizing all forms of nitrogen to nitrate by alkaline persulfate digestion. The sixth nitrogen analyte, particulate nitrogen (PN, parameter code 49570), is determined from analysis of the residue on a filter and does not include any dissolved forms.

Total phosphorus includes dissolved phosphate and particulate organic phosphorus, which is often attached to sediment. Phosphates are compounds of phosphorus, oxygen, and hydrogen, including orthophosphate, which is the predominant form of dissolved phosphorus in natural water. Phosphates are moderately soluble and tend to adhere to soil particles.

Pesticides are used to control weeds, insects, or other unwanted organisms and provide benefits such as increased food production and reduction of insect-borne disease but can also raise questions about possible adverse effects on the environment (Gilliom and others, 2006). Pesticides are released 
into the environment primarily through application onto agricultural lands as well as some nonagricultural lands like lawns and gardens, commercial areas, and rights-of-way. Factors that influence movement of pesticides and their degradates through the hydrologic system include intensity and distribution of use, climate and soil characteristics, and physical and chemical properties of the pesticide compounds (Gilliom and others, 2006). Pesticides enter streams during events such as rainfall or irrigation by surface runoff; through shallow subsurface flow, through drainage ditches and subsurface tile drains; or continuously from groundwater. Compounds such as atrazine easily dissolve in and move with water. Other compounds, such as chlorpyrifos, associate and are transported with solid particles and eroded soil. Once in a stream, a pesticide may transform, be taken up by aquatic organisms, attach to suspended particles and be deposited in bed sediment, or volatilize to the atmosphere.

\section{Data Collection and Analysis}

General procedures for environmental and QC sample collection, processing, and shipping are described in the USGS NFM (U.S. Geological Survey, variously dated) and are summarized in this section. This section also describes methods of laboratory and data analysis. In addition to procedures described in this report, quality-assurance procedures used at the NWQL are documented at http://nwql.usgs.gov/Public/ quality.shtml. Independent quality monitoring of the NWQL is provided by the USGS Branch of Quality Systems (https://bqs. usgs.gov/).

\section{Procedures for the Collection of Field Blanks and Environmental Samples}

Equipment-cleaning, sampling, and processing protocols for the collection of QC and environmental samples are described in chapters A4 and A5 of the USGS NFM (U.S. Geological Survey, variously dated). In brief, equipment is cleaned in the laboratory with phosphate-free detergent and rinsed with tap water, then soaked in acid and rinsed with deionized water (for inorganic constituents) or rinsed in methanol and either air dried or rinsed with organic-grade water (for organic compounds). For organic compounds, cleaning at field sites is the same as in the laboratory; for inorganic constituents, the detergent wash is replaced with a deionized water rinse, and the acid soak is replaced with an acid rinse. Tefloncoated isokinetic samplers are used to collect surface-water samples for analysis of nutrients and pesticides; the samples are subject to flow-weighted, depth- and width-integrated collection procedures. Samples collected by following these procedures are composited, split, and then possibly filtered and preserved according to the laboratory schedule. Sample water is composited and then split into separate bottles by using a Teflon cone or churn splitter. Water samples for dissolved nutrient analyses are filtered by using a capsule filter system with pressure supplied by a peristaltic pump and are placed on ice. Pesticide samples are filtered through glass-fiber filters with a nominal 0.7 -micrometer pore diameter into amber glass bottles and placed on ice. Neither nutrient nor pesticide sample bottles are treated with a preservative before shipment on ice to the NWQL in Denver, Colorado.

Field blanks collected from October 1, 2001, through May 31, 2006, for nutrients could have used inorganic-grade blank water or universal (pesticide-grade or volatile organic compound/pesticide-grade) blank water; field blanks collected for pesticides used universal blank water. Beginning June 1, 2006, USGS Office of Water Quality policy discontinued the use of universal blank water for inorganic applications, including nutrients, because of potential contamination (Office of Water Quality Information Note 2006.11, written commun., June 1, 2006).

\section{Laboratory Analytical Methods and Schedules}

The nutrient analytes presented in this report (table 2) are species of nitrogen and phosphorus that were sampled for some or all of cycle 2 at NAWQA and (or) NASQAN sites. Inconsistencies between historical USGS water-quality networks and over time in methods and schedules for nitrogen analytes are important to note. Although sample collection protocols generally followed the NFM and analyses of all samples presented in this report were at the NWQL, major differences in protocols between NAWQA and NASQAN, the two major historical USGS water-quality networks, include (1) the suite (schedule) of analytes to measure, (2) the selection of laboratory analytical method, and (3) the method of calculation of total nitrogen. Independent of program differences, methods of analysis at the NWQL have evolved during cycle 2 for some of the nutrient analytes. An additional characteristic of cycle 2 data is that along with (or independent of) analytical method changes, reporting limits, reassessed annually, have changed for some analytes.

NAWQA typically used schedule 2711 or 2120 for nutrient samples, and NASQAN typically used schedule 1010 for environmental samples and 452 and 1675 for blank samples. Use of different schedules for a given analyte does not mean that different analytical methods were used. At the beginning of cycle 2, the NWQL offered two methods ${ }^{4}$ for all dissolved nutrients, depending on whether concentration levels were expected to be low or standard. For all dissolved analytes except nitrite plus nitrate, a single replacement method for all expected concentrations became available in 2006. By design, field blanks collected by NASQAN were analyzed by using low-level methods (CL039, CL043, CL050, CL057, and CL021; method abbreviations in green font, table 2), and those collected by NAWQA were analyzed by using standard-level methods (method abbreviations in orange font, table 2).

\footnotetext{
${ }^{4}$ Analytical methods are presented in this report using the 5-digit internal laboratory code that is embedded in the analyte ID field in the NWQL online catalog (http://nwql.cr.usgs.gov/usgs/catalog/index.cfm).
} 


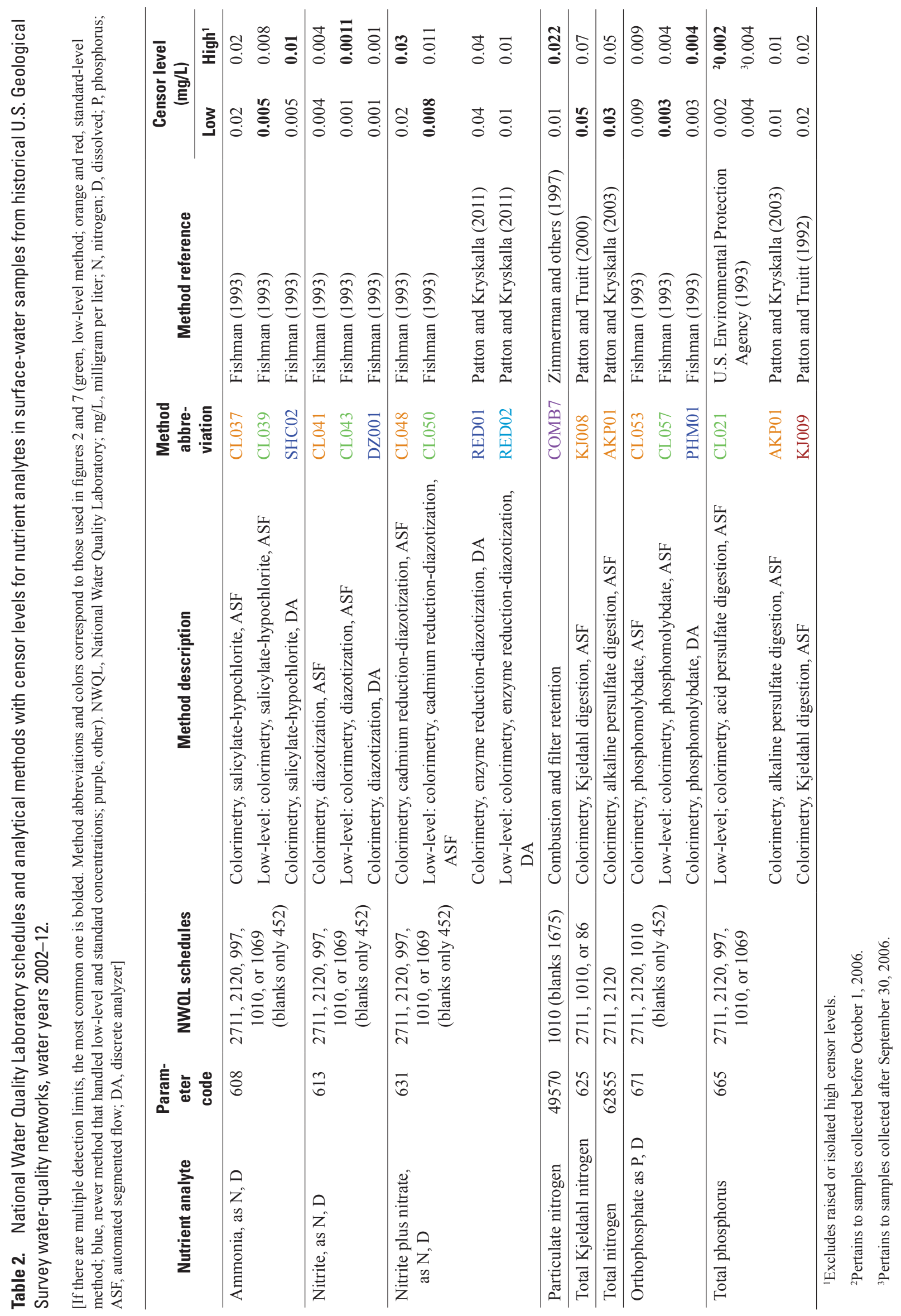


The determination of total nitrogen varied by network and over time. Except for the rest of this paragraph, "total nitrogen" in this report refers only to samples analyzed with alkaline-persulfate digestion (parameter code 62855) and does not include calculated results. As summarized by Rus and others (2012), three methods used by the USGS during cycle 2 to determine total nitrogen were alkaline-persulfate digestion of whole water samples, the sum of TKN and dissolved nitrite plus nitrate, and the sum of PN and dissolved nitrogen. In 2004, NAWQA switched from measuring total nitrogen as the sum of components to using the alkaline-persulfate digestion method for whole-water samples, while continuing to analyze also for individual dissolved species. NASQAN maintained consistency over cycle 2 by measuring total nitrogen as the sum of PN and the dissolved nitrogen analytes and never switched to the alkaline-persulfate digestion method. A synoptic field study comparing precision and bias among these different methods of measuring total nitrogen resulted in some overlap of nitrogen analytes for environmental samples among networks during June 2009 and September 2010 (Rus and others, 2012).

The 40 pesticides or pesticide degradates analyzed for this report (table 3 ) are the subset out of hundreds of pesticides and degradates analyzed at the NWQL that were common to at least 3 of the 4 NWQL schedules of pesticides (2001, 2003, 2010, and 2033) typically used for USGS surfacewater network sites during 2002-12. The laboratory method used to analyze pesticides in all of these schedules was gas chromatography/mass spectrometry (GCMS). Water samples analyzed by GCMS are prepared for analysis by C-18 solidphase extraction followed by capillary-column GCMS using selected-ion monitoring (Zaugg and others, 1995; Madsen and others, 2003). Pesticide extraction is done at the NWQL for all schedules except 2010, where it is done in the field. Other than place of extraction, schedule 2010 is identical to schedule 2001. Schedule specification frequently changed over time and differed by water-quality network, but GCMS was exclusively used for all pesticide results in this report. Schedule 2001 was used extensively by NAWQA and NASQAN in the early 2000s, schedule 2033 was used extensively by NAWQA and NASQAN in the latter years of the study period (Martin and others, 2011; David Reutter, U.S. Geological Survey, written commun., May 18, 2015), schedule 2003 was used extensively by NAWQA during 7 months of 2005, and schedule 2010 was the least frequently used. One sample collected during 2002 from a station in the NMN used schedule 2001; all subsequent samples from stations in the NMN used schedule 2033.
Table 3. National Water Quality Laboratory schedules for pesticide analytes in surface-water samples from historical U.S. Geological Survey water-quality networks, water years 2002-12.

[NWQL, National Water Quality Laboratory]

\begin{tabular}{|c|c|c|}
\hline Pesticide analyte & $\begin{array}{c}\text { Parameter } \\
\text { code }\end{array}$ & NWQL schedules \\
\hline Simazine & 4035 & 2001, 2003, 2010, 2033 \\
\hline Prometon & 4037 & 2001, 2003, 2010, 2033 \\
\hline Deethylatrazine & 4040 & 2001, 2003, 2010, 2033 \\
\hline Cyanazine & 4041 & $2001,2010,2033$ \\
\hline Fonofos & 4095 & $2001,2003,2010,2033$ \\
\hline Chlorpyrifos & 38933 & 2001, 2003, 2010, 2033 \\
\hline Dieldrin & 39381 & $2001,2003,2010,2033$ \\
\hline Metolachlor & 39415 & 2001, 2003, 2010, 2033 \\
\hline Malathion & 39532 & 2001, 2003, 2010, 2033 \\
\hline Diazinon & 39572 & $2001,2003,2010,2033$ \\
\hline Atrazine & 39632 & $2001,2003,2010,2033$ \\
\hline Alachlor & 46342 & 2001, 2003, 2010, 2033 \\
\hline Acetochlor & 49260 & 2001, 2003, 2010, 2033 \\
\hline Fipronil & 62166 & $2001,2003,2010,2033$ \\
\hline Fipronil sulfide & 62167 & $2001,2003,2010,2033$ \\
\hline Fipronil sulfone & 62168 & $2001,2003,2010,2033$ \\
\hline Desulfinylfipronil amide & 62169 & 2001, 2003, 2010, 2033 \\
\hline Desulfinylfipronil & 62170 & 2001, 2003, 2010, 2033 \\
\hline Metribuzin & 82630 & $2001,2003,2010,2033$ \\
\hline 2,6-Diethylaniline & 82660 & $2001,2003,2010,2033$ \\
\hline Trifluralin & 82661 & 2001, 2003, 2010, 2033 \\
\hline Phorate & 82664 & 2001, 2003, 2010, 2033 \\
\hline Methyl parathion & 82667 & 2001, 2003, 2010, 2033 \\
\hline ЕРTC & 82668 & $2001,2010,2033$ \\
\hline Tebuthiuron & 82670 & $2001,2003,2010,2033$ \\
\hline Molinate & 82671 & $2001,2010,2033$ \\
\hline Ethoprophos & 82672 & $2001,2010,2033$ \\
\hline Benfluralin & 82673 & 2001, 2003, 2010, 2033 \\
\hline Carbofuran & 82674 & $2001,2010,2033$ \\
\hline Terbufos & 82675 & $2001,2003,2010,2033$ \\
\hline Propyzamide & 82676 & $2001,2003,2010,2033$ \\
\hline Disulfoton & 82677 & $2001,2010,2033$ \\
\hline Propanil & 82679 & $2001,2010,2033$ \\
\hline Carbaryl & 82680 & $2001,2003,2010,2033$ \\
\hline Thiobencarb & 82681 & $2001,2010,2033$ \\
\hline Dacthal & 82682 & $2001,2003,2010,2033$ \\
\hline Pendimethalin & 82683 & $2001,2003,2010,2033$ \\
\hline Propargite & 82685 & $2001,2010,2033$ \\
\hline Azinphos-methyl & 82686 & $2001,2003,2010,2033$ \\
\hline cis-Permethrin & 82687 & $2001,2003,2010,2033$ \\
\hline
\end{tabular}




\section{Representation of Results}

Because of the nature of field blanks, large percentages of nutrient and pesticide results are censored, or reported as "less than." Two features related to NWQL policies on censoring are critical for understanding data in this report. First, censor levels may change from year to year, and changeable censor levels can complicate data summaries and other statistics. Second, data qualifiers used extensively by the NWQL for censored results have specific meanings that may differ for nutrients and pesticides.

NWQL policies of how to report censored results change over time. For chemical results generated through September 30, 2010, NWQL policy was to provide censored results at the laboratory reporting level (LRL), which at typically two times the long-term method detection level (LTMDL) ${ }^{5}$ met a policy goal to minimize the incidence of false negatives (Childress and others, 1999; Bonn, 2008). Although the LRL is the default censor level for data reported in the National Water Information System (NWIS, the national repository of USGS water data), censored results are stored in the NWQL database for both the LRL and the LTMDL. In order to prevent bias for purposes of this report and to minimize loss of information, data originally provided as less than the LRL were recensored, or changed to less than the LTMDL. Despite increasing the risk of false-negative error by up to 50 percent, recensoring is an acceptable practice for characterizing the distribution of data as long as uncertainty in individual values can be tolerated (Bonn, 2008, p. 43, least conservative approach). Values that have been recensored are documented in the "Recensor note" field of appendixes 1 and 2 .

If applicable, the NWQL provides remarks with chemical results. Before October 1, 2010, the most commonly used remarks were "E" for estimated and " $<$ " for less than (not detected). An "E" remark was given when concentrations were extrapolated beyond the calibration curve or to indicate a lesser likelihood of precision in the result. All quantified (not censored) values less than the LRL automatically were given an "E" remark. Uniquely for pesticides analyzed by GCMS, the " $E$ " code also was used to indicate where pesticides were detected and conclusively identified, and where the quantified result was less than the LTMDL (Childress and others, 1999; Zaugg and others, 1995). Nutrient results could be presented as quantified only if less than the LRL; they could not be quantified if less than the LTMDL. All quantified results, whether estimated or not (unremarked), are used in the same way for summaries and other representations in this report.

${ }^{5}$ The LTMDL, similar to the U.S. Environmental Protection Agency (1997) method detection limit, is defined as the smallest concentration that can be measured and reported with 99-percent confidence that the analyte concentration is greater than zero. It is determined annually for each analyte/method combination.
Beginning October 1, 2010, the NWQL set the LRL at the LTMDL for inorganic analytes, and use of the "E" remark code was replaced by use of more specific remark codes. An "n" remark code indicated results between the LTMDL and two times the LTMDL", and "b" indicated results less than the lowest calibration standard (Donna N. Myers, U.S. Geological Survey, written commun., September 28, 2010). Also, " $t$ " replaced the "E" remark code after October 1, 2010, for results of organic analytes (all pesticides analyzed by using GCMS) that were less than the LTMDL.

Because of annual reevaluations, many LRLs and LTMDLs changed, in some cases several times, during the 11 years covered in this report. Furthermore, the NWQL occasionally reports censored results as "raised LRLs," where the censor level is higher than the routine LRL. Raised LRLs are used by the laboratory when samples need to be diluted to bring them within the calibration range. They also can indicate matrix effects or interference problems during analysis.

Although multiple censor levels are a potential complication in summarizing or analyzing data (Helsel and Hirsch, 2002), the key distinction for all of the data analysis in this report is between detections and nondetections. In the section "Assessment of Contamination and Implications for the Interpretation of Environmental Data," additional recensoring is not necessary because all detections (quantified values) are ranked higher than all nondetections (censored values) (Bonn, 2008, p. 43; Bender and others, 2011, fig. 7, p. 36). This convention poses no issue for nutrients for which all quantified values are above the LTMDL. The contrived ranking ${ }^{7}$ also is justified for pesticides because pesticide results that are censored by the NWQL can be interpreted as having concentrations of zero in almost all cases, making it appropriate to rank quantified results higher than censored results (Mark Sandstrom, U.S. Geological Survey, written commun., February 12 , 2016). Recensoring to a common censor level, needed for analyzing trends (Martin and others, 2011) or for calculating certain kinds of summary results, is not appropriate here- the loss of information would be unnecessary.

To summarize how data were handled for this report, results were not recensored to change multiple LRLs to a common LRL (except where noted), but results were recensored from the LRL to the LTMDL. From this point forward in the report, "censor level" means the LTMDL and "routine censor level" means any LTMDL or LRL determined annually by the NWQL during the report period, as distinguished from a raised LRL.

\footnotetext{
${ }^{6}$ For inorganic and organic analytes, $2 \times L T M D L$ was the conventional LRL before October 1, 2010. The only difference after October 1, 2010, was that $2 \times L T M D L$ was still the LRL for organic analytes but was not the LRL for inorganic analytes.

${ }^{7} \mathrm{~A}$ common statistical method for a censored dataset is to recensor everything at the highest censor level so that all quantified and censored results less than that level have equal ranks (Helsel, 2012).
} 


\section{Data Retrieval, Processing, and Screening}

All field-blank and environmental analytical results presented in this report were retrieved from NWIS (Casey J. Lee, U.S. Geological Survey, written commun., October 24, 2014, and July 16, 2015). Field-blank and environmental pesticide data through September 15, 2010, for many of the sites that had been reviewed and corrected for an earlier project (Martin and others, 2011), also were integrated. Sample information and analytical results are entered into NWIS either by the NWQL or the individual USGS water science center responsible for data collection. Some water-quality network managers perform various types of preliminary data checks designed to identify and fix missing or erroneous results and codes (such as for type of water: ground or surface; or type of sample: environmental, replicate, spike, or blank). However, because not all of these data checks were done routinely from the beginning of cycle 2 , all data presented here were subject to the procedures described in the following paragraphs.

Duplicate entries, erroneous entries (where data have been rejected by the NWQL or the sample collector), and extraneous entries (such as composite samples) were screened out. Results that indicated a non-NWQL laboratory were not used. The NWQL was assumed to be the analyzing laboratory in the absence of a specified laboratory in NWIS.

A result was determined to be a field blank if the NWIS coding of the record designated that the medium type was artificial (coded OAQ) and the blank-solution type was field blank (where parameter code 99102 has a value of 100) unless there was evidence that indicated the field blank was miscoded. Environmental samples were those where the medium type was regular surface water (coded as WS). Evidence to justify changes in coding for specific data records are recorded in a comment field of appendixes 1 and 2.

Potential errors in data or coding, unavoidable because of the large number of samples collected by many different individuals, were identified in several ways. Exploratory time-series plots for each constituent helped identify outliers in field-blank results. Outliers were assessed individually by examining all available data associated with the record, including comments recorded in NWIS by the NWQL or by the water science center, type of quality assurance (QA) sample, purpose of site visit, and QA results for other constituents analyzed as part of the sample. In some cases, results of this examination revealed a systematic problem for all results associated with a particular sample, such as an apparent switch of environmental and field-blank results. A data check for nutrients was whether total forms of nitrogen and phosphorus were greater than the sum of the dissolved species. If no information was gleaned from other parameters in the record, then the result was looked up in the NWQL Laboratory Information Management System (LIMS) and compared to other results over time, both environmental and blank, for the parameter for that site. Occasionally, the request-for-services form in LIMS provided some information about the type of sample that was not recorded in NWIS. If no evidence was found to justify modification or flagging of an anomalous result, then the result was kept in the dataset under the assumption that it reflected real contamination.

A second use of the exploratory time-series plots was to partition potential contamination bias in nutrients attributable to different analytical methods. The possibility that contamination bias was related to analytical method was not a concern for pesticides, which were all analyzed by GCMS. Missing information about analytical method in the original nutrient data was filled in by matching existing sample information (date and constituent) with information from an NWQL lookup table that included constituent, date range, analytical method, LTMDL, and routine LRL. For ammonia, nitrite, nitrite plus nitrate, and orthophosphate, analyses geared toward either low- or standard-level concentrations were offered in the early part of cycle 2 , with the selection of analytical method determined by sampling network guidance. Newer methods developed during cycle 2 for these analytes were able to handle low- and standard-level concentrations equally well (method abbreviations in blue font, table 2), rendering separate low-level analyses unnecessary. Methods for PN, TKN, and total nitrogen did not change. Most field blanks analyzed for total phosphorus used the low-level method throughout cycle 2. Differences noted in nutrient field-blank results among analytical methods are not necessarily related to contamination.

Patterns in grouped data also were examined with the goal of identifying factors that might influence interpretation of contamination bias. Quantified results were examined for unusual patterns among type of site (agriculture, coastal, integrator, large inland, reference, or urban), first two digits of site number used as a surrogate for differences related to geography, and historical USGS water-quality network (CWP, NASQAN, NAWQA, or NMN). The two-digit site number comes from stripping the first two-digits from each USGS station number ${ }^{8}$ for use as the grouping element (http://help. waterdata.usgs.gov/faq/sites/do-station-numbers-have-anyparticular-meaning), which designates the major river basin. For example, two-digit site number " 06 " is the Missouri River Basin. Ascending two-digit site numbers generally traverse the United States from east to west. Sites indicated in table 1 as coincident with NASQAN and NAWQA were assigned singly to NAWQA, unless information was available otherwise. In addition, we examined pesticide results to assess potential differences among sample-processing procedures; in particular, we examined whether there was a difference between schedule 2010, according to which extractions were done in the field,

${ }^{8}$ For the two stations with 15 -digit station numbers, the two-digit site number comes from the first two digits of the associated USGS streamflow station number listed in the footnotes in table 1. 
and the other schedules, according to which extractions were done in the laboratory. Unusual patterns in any of the exploratory plots described in this paragraph were evaluated and decisions for what to do were made on a case-by-case basis.

\section{Method Used to Determine Potential Contamination Bias}

The general approach for determination of contamination bias as part of quality assessment is to infer the distribution of contamination in environmental samples on the basis of the characterization of the frequency and magnitude of contamination in field-blank samples (Mueller and others, 2015). Assumptions behind the inference are that the same sources of extraneous contamination and the same magnitude of contamination apply to both field-blank and environmental samples (Mueller and others, 2015).

The frequency of contamination is determined by calculating the one-sided upper confidence limit (UCL) on the percentage of detections of field blanks at a specified level of confidence. In this report, the level of confidence is specified as 95 percent for nutrients and, because nearly all pesticide results are censored, 99 percent for pesticides. The UCL calculation is based on the F-statistic with two degrees of freedom (for the numerator and denominator of the fraction of detections) for the specified level of confidence (Hahn and Meeker, 1991; Mueller and others, 2015). The approach to adjusting the detection frequency in environmental samples for the frequency of contamination in field blanks at a given confidence is to set the upper bound as the measured detection frequency in environmental samples and the lower bound as the measured frequency minus the 95- or 99-percent UCL for the percentage of detections in field blanks (Martin, 1999).

For assessing magnitude, the approach is to determine the amount of contamination that is not likely to be exceeded in a large percentage of the water samples represented by the blanks (Mueller and Titus, 2005). Having a large number of field-blank results enables meaningful calculations with high levels of confidence. For nutrient analytes, UCLs were constructed at a 95-percent level of confidence for the 95th and 99th percentiles of concentrations of field blanks. These UCLs are the largest amount of contamination expected, with 95-percent confidence, for the 95th and 99th percentiles of water samples. Contamination could be higher for the remaining 5 or 1 percent of samples. In other words, the 95-percent UCL for the 95th percentile of concentrations in blanks is likely to be exceeded in no more than 5 percent of all water samples. For pesticides, the UCL is calculated at a 99-percent level of confidence for the 98th percentiles of water samples. Details on calculations using order statistics and binomial probability to determine the distribution-free UCL for various percentiles can be found in Mueller and others (2015). Plots of percentiles of concentration in relation to UCLs for detections in field blanks and the distribution of environmental samples offer a visual representation of potential contamination bias and help provide a context for interpreting environmental significance.

To establish the maximum concentration of nutrient analytes that potentially could be affected by contamination, the convention is to use 10 times the 95 th percentile of field blanks based on the 95-percent UCL. The rationale is that if potential contamination is less than 10 percent of a measured value, the effect of contamination bias on that measured value has essentially no practical significance and can be ignored (Mueller and Titus, 2005). Using the same rationale, we establish the maximum concentration of pesticides that potentially could be affected as 10 times the 98th percentile of field blanks based on the 99-percent UCL. The percentile and percent UCL are greater for pesticides than for nutrients because the high percentage of censored field-blank results enables us to make statements about potential contamination bias with high confidence.

\section{Summary of Analytical Methods, Censoring, and Data From Field Blanks}

Here we provide a descriptive summary of field-blank results and describe changes over time for some analytical methods and for some censor levels. Patterns in detections in field blanks related to type of site, two-digit site number, or sampling network that could be important in the interpretation of associated environmental data are explored.

\section{Nutrients}

The number of field blanks for nutrients collected during water years 2002-12 from the 147 surface-water sites included in this report ranged from 159 to 693 (table 4, totals bolded), which were 2 to 5 percent of environmental samples. Of the eight nutrient analytes investigated, nitrite had the lowest percentage of field-blank detections (4.3 percent), and PN had the highest percentage (22 percent). All of the dissolved species (table 4, method totals) except ammonia had detections in fewer than 10 percent of field blanks; ammonia, TKN, PN, total nitrogen, and total phosphorus had detection rates greater than 10 percent. Higher detection rates in particulate and total analytes compared to dissolved analytes might be associated with processing errors in laboratory subsampling procedures (Mueller and Titus, 2005). An analysis of potential contamination bias for cycle 1 data collected between water years 1992 and 2001 also found a relatively large percentage of detections of ammonia in field blanks compared to other nutrients; the source of contamination was determined to be the source solution of the blank water itself or shipping or laboratory procedures (Mueller and Titus, 2005). Ammonia samples are susceptible to airborne contamination from the laboratory environment (Fishman, 1993). 
Table 4. Number and detection rates of field-blank and environmental samples and upper confidence limits for percent detections and concentrations in field blanks for selected percentiles, for nutrient analytes in surface-water samples from historical U.S. Geological Survey water-quality networks, water years 2002-12.

[Colors correspond to those used in figures 2 and 7. Bold text indicates the total for the analyte. $\mathrm{mg} / \mathrm{L}$, milligram per liter; $<$, less than]

\begin{tabular}{|c|c|c|c|c|c|c|c|c|c|}
\hline \multirow{3}{*}{ Nutrient analyte } & \multirow{3}{*}{$\begin{array}{c}\text { Parameter } \\
\text { code }\end{array}$} & \multirow{3}{*}{$\begin{array}{c}\text { Method } \\
\text { abbreviation } \\
\text { (defined in } \\
\text { table 2) }\end{array}$} & \multicolumn{5}{|c|}{ Field blanks } & \multicolumn{2}{|c|}{$\begin{array}{l}\text { Environmental } \\
\text { samples }\end{array}$} \\
\hline & & & \multirow{2}{*}{ Number } & \multirow{2}{*}{$\begin{array}{c}\text { Percent } \\
\text { detections }\end{array}$} & \multicolumn{3}{|c|}{ 95-percent upper confidence limit } & \multirow{2}{*}{ Number } & \multirow{2}{*}{$\begin{array}{c}\text { Percent } \\
\text { detec- } \\
\text { tions }\end{array}$} \\
\hline & & & & & $\begin{array}{c}\text { For } \\
\text { percent } \\
\text { detections }\end{array}$ & 95th & 99th & & \\
\hline \multirow{3}{*}{ Ammonia } & & CL039 & 67 & 13 & 22 & 0.0190 & 0.0190 & 261 & 73 \\
\hline & & SHC02 & 363 & 27 & 31 & 0.0187 & 0.0462 & 7,936 & 67 \\
\hline & & Total & 669 & 17 & & & & 14,307 & 56 \\
\hline Nitrite & 613 & CL041 & 234 & 1.7 & 4 & $<0.004$ & 0.0110 & 5,996 & 75 \\
\hline \multirow[t]{5}{*}{ Nitrite plus nitrate } & 631 & CL048 & 505 & 5.0 & 7 & $<0.030$ & 0.038 & 12,433 & 96 \\
\hline & & CL050 & 142 & 14 & 20 & 0.0160 & 0.5611 & 751 & 98 \\
\hline & & RED01 & 36 & 2.8 & 13 & 0.0449 & 0.0449 & 1,136 & 95 \\
\hline & & RED02 & 10 & 20 & 51 & 0.0158 & 0.0158 & 88 & 93 \\
\hline & & Total & 693 & 6.9 & & & & 14,408 & 96 \\
\hline Particulate nitrogen & 49570 & COMB7 & 315 & 22 & 26 & 0.0700 & 0.1320 & 6,439 & 96 \\
\hline Total Kjeldahl nitrogen & 625 & KJ008 & 159 & 14 & 20 & 0.1200 & 0.2900 & 7,088 & 100 \\
\hline Total nitrogen & 62855 & AKP01 & 370 & 11 & 14 & 0.0640 & 0.4410 & 7,613 & 100 \\
\hline Orthophosphate & 671 & CL053 & 125 & 0.8 & 4 & $<0.009$ & 0.0090 & 3,176 & 70 \\
\hline \multirow{3}{*}{ Total phosphorus } & & AKP01 & 40 & 0 & 7 & $<0.010$ & $<0.010$ & 1,819 & 100 \\
\hline & & KJ009 & 12 & 0 & 21 & $<0.02$ & $<0.02$ & 2,046 & 99 \\
\hline & & Total $^{4}$ & 523 & 15 & & & & 14,346 & 99 \\
\hline
\end{tabular}

${ }^{1}$ For this calculation, concentrations have been recensored to the maximum censor level that was used for more than one year.

${ }^{2}$ Pertains to samples collected before October 1, 2006.

${ }^{3}$ Pertains to samples collected after September 30, 2006.

${ }^{4}$ Totals in this row do not include values in the shaded rows. 
Time-series plots of cycle 2 nutrient results distinguished by analytical method show changing censor levels over time and concentrations of field blanks relative to environmental samples (fig. 2). Low-level method results are shown with green symbols, and standard-level results are orange. For ammonia, nitrite, nitrite plus nitrate, and orthophosphate, color-coded symbols embed information about whether NAWQA or NASQAN collected the samples. Guidance for selection of the low- or standard-level analytical method was issued by the individual sampling network. Because hydrologists submitting NASQAN samples to the NWQL were advised to "select the appropriate schedule for your stations to avoid non-detects" based on expected concentrations (Office of Water Quality Technical Memorandum 2008.01, written commun., November 7, 2007), low-level analyses were used for NASQAN field blanks. NAWQA hydrologists were not given a choice of schedule or of low-level methods - standardlevel methods were the only option.

For ammonia, nitrite, and orthophosphate (table 2; figs. $2 A, 2 B$, and $2 G$ ), the introduction of analytical methods that used discrete analyzer flow systems in water year 2007 eliminated the need for separate low- and standard-level methods that used automated-segmented flow systems. For the dataset described in this report, samples analyzed using discrete-analyzer methods (SHC02 for ammonia, DZ001 for nitrite, and PHM01 for orthophosphate) accounted for the largest number of field blanks for each analyte in cycle 2 (table 4). Two analytical methods, each with a low-level adaptation, were used by the NWQL during cycle 2 to determine nitrite plus nitrate concentrations in water samples (table 2; fig. 2C). Methods that used cadmium reduction (CL048 and CL050) were superseded in October 2011 by methods that used enzyme reduction-diazotization (RED01 and RED02), which did not require use of cadmium, a hazardous material. All 315 field-blank and 6,439 environmental sample results for PN were analyzed by using a combustion and filter retention method (COMB7), which performs the analysis on solid particles from a filter rather than on water.

Field blanks for ammonia and orthophosphate had more detections beginning in 2007, when low- and standard-level methods were replaced with a single method (table 4; fig. $2 A$ and $2 G$ ). Although nitrite had the highest percentage of detections when the low-level method (CL043) was used, more of the detections were higher than the censor level when the single combined method (DZ001) was used than when method CL043 was used (fig. 2B). If all results for these analytes throughout the record were recensored to the standard-level censor limit, there would be far fewer detections throughout the period, and the difference in the number of detections before and after the method changes in 2007 would be negligible. ${ }^{9}$ The increase in detections beginning in 2007 apparently relates to different analytical choices that led to more frequent

\footnotetext{
${ }^{9}$ Perhaps difficult to discern from figure $2 \mathrm{~A}$, the number of detections in ammonia field blanks above the standard-level (CL037) censor limit of 0.02 milligram per liter is minimally different before and after the method change (6 detections before and 8 after) in 2007.
}

detections at low concentrations rather than to inherent differences in the field blanks or their processing. Ammonia, uniquely, might warrant extra consideration because water samples are easily contaminated by ammonia in the laboratory atmosphere (Fishman, 1993, p. 119), and the change in method might have resulted in a change in potential ammonia contamination of all samples (blanks and environmental).

Colorimetry with Kjeldahl digestion (method KJ008) was used for all samples analyzed for TKN during cycle 2 (table 2). Unlike the other nutrient analytes, the ratio of TKN field blanks to environmental samples was not consistent through cycle 2; it dropped from 3 percent before 2004 to 1 percent beginning in 2004 (fig. $2 E$ ). The percentage of field blanks with TKN detections was the same, about 14 percent, for both periods, although it jumped to 19 percent for just 2003. Laboratory and field experiments have shown generally positive biases in TKN possibly as a result of the reduction of nitrate to ammonia during the digestion process (Rus and others, 2012).

Total nitrogen (parameter code 62855) samples were analyzed by a single method, AKP01, during cycle 2 (table 2 ; fig. $2 F$ ). Rus and others (2012) estimated a median negative bias of approximately 13.2 percent in the determination of total nitrogen concentrations by using AKP01 in the presence of suspended sediment, addressed issues of data continuity, and described tradeoffs for various determinations of total nitrogen.

Three analytical methods with different digestion procedures, all using automated-segmented flow colorimetry, were used to analyze for total phosphorus in surface water during the report period (table 2). The low-level method (CL021), used most often during the period, used an acid persulfate digestion process; a second method used alkaline persulfate digestion (AKP01); and a third method used Kjeldahl digestion (KJ009). Although all 78 quantified results for total phosphorus in field blanks were observed when method CL021 was used (table 4; fig. $2 H$ ), only 5 were greater than the censor level for method AKP01 (method KJ009 had too few samples for an adequate comparison).

An additional way to consider partitioning the nutrient field blanks in the assessment of potential contamination bias is to look at changes in censor levels over time within particular analytical methods; for example, partitioning should be considered for method AKP01 for total nitrogen and method CL021 for total phosphorus. In October 2006, when the censor level doubled for the most commonly used method for total phosphorus (CL021) from 0.002 to 0.004 milligram per liter $(\mathrm{mg} / \mathrm{L})$, the number of detections above $0.004 \mathrm{mg} / \mathrm{L}$ increased more than 6 times (from 4 before to 27 after 2007; fig. 2H). In contrast, a marginal effect on the number of detections for total nitrogen was seen (an increase from 7 to 10 detections above $0.05 \mathrm{mg} / \mathrm{L}$ ) after October 2008 when the censor level increased for method AKP01. Consequently, it could be important to consider the date of the change of censor level for total phosphorus when assessing potential contamination bias for environmental samples. 

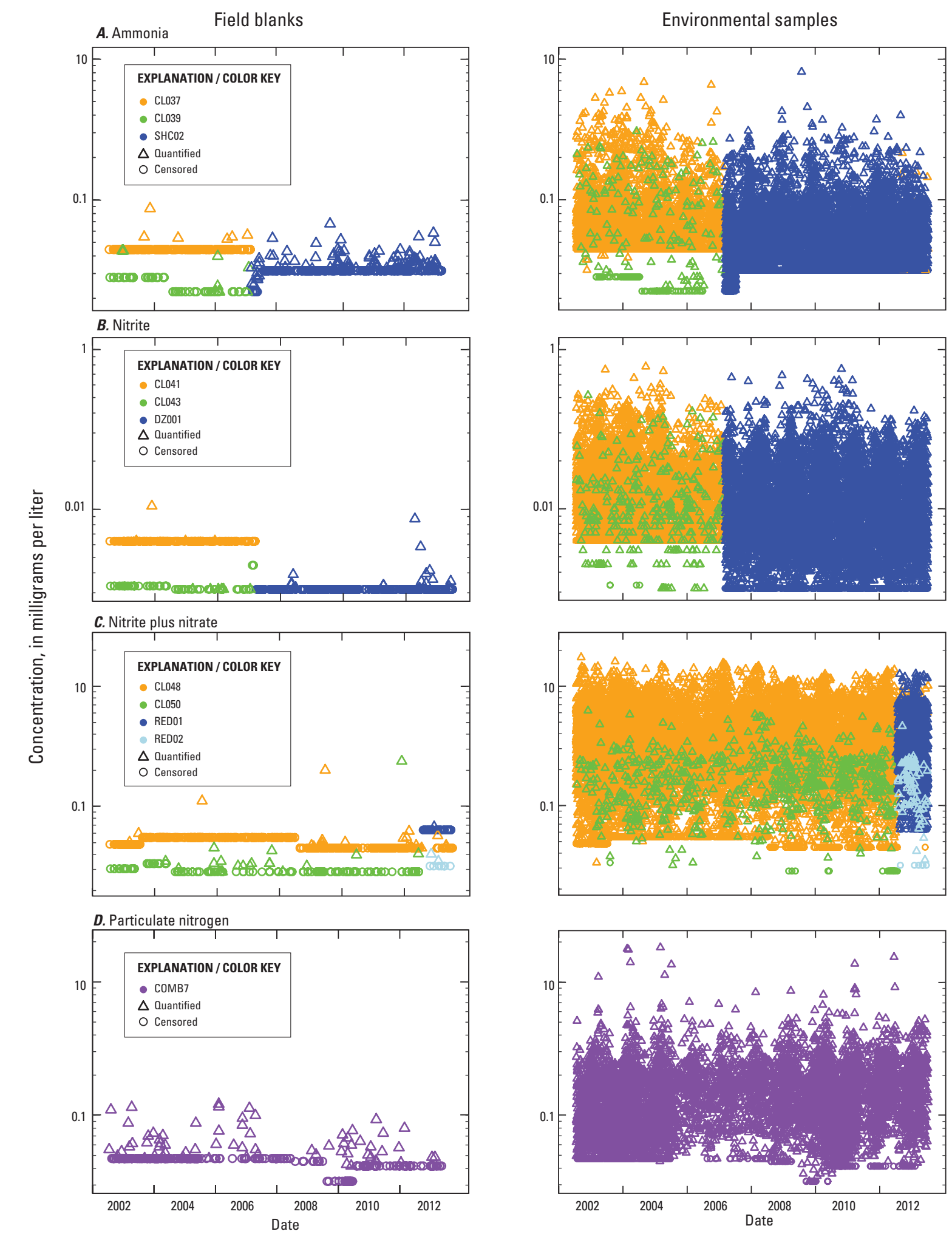

Figure 2. Concentrations, distinguished by analytical method, of $A$, ammonia; $B$, nitrite; $C$, nitrite plus nitrate; $D$, particulate nitrogen; $E$, total Kjeldahl nitrogen; $F$, total nitrogen; $G$, orthophosphate; and $H$, total phosphorus in fieldblank and environmental surface-water samples from historical U.S. Geological Survey water-quality networks, water years 2002-12. Fewer than 0.1 percent of environmental samples may not be shown to optimize scaling. Analytical methods are described in table 2. 

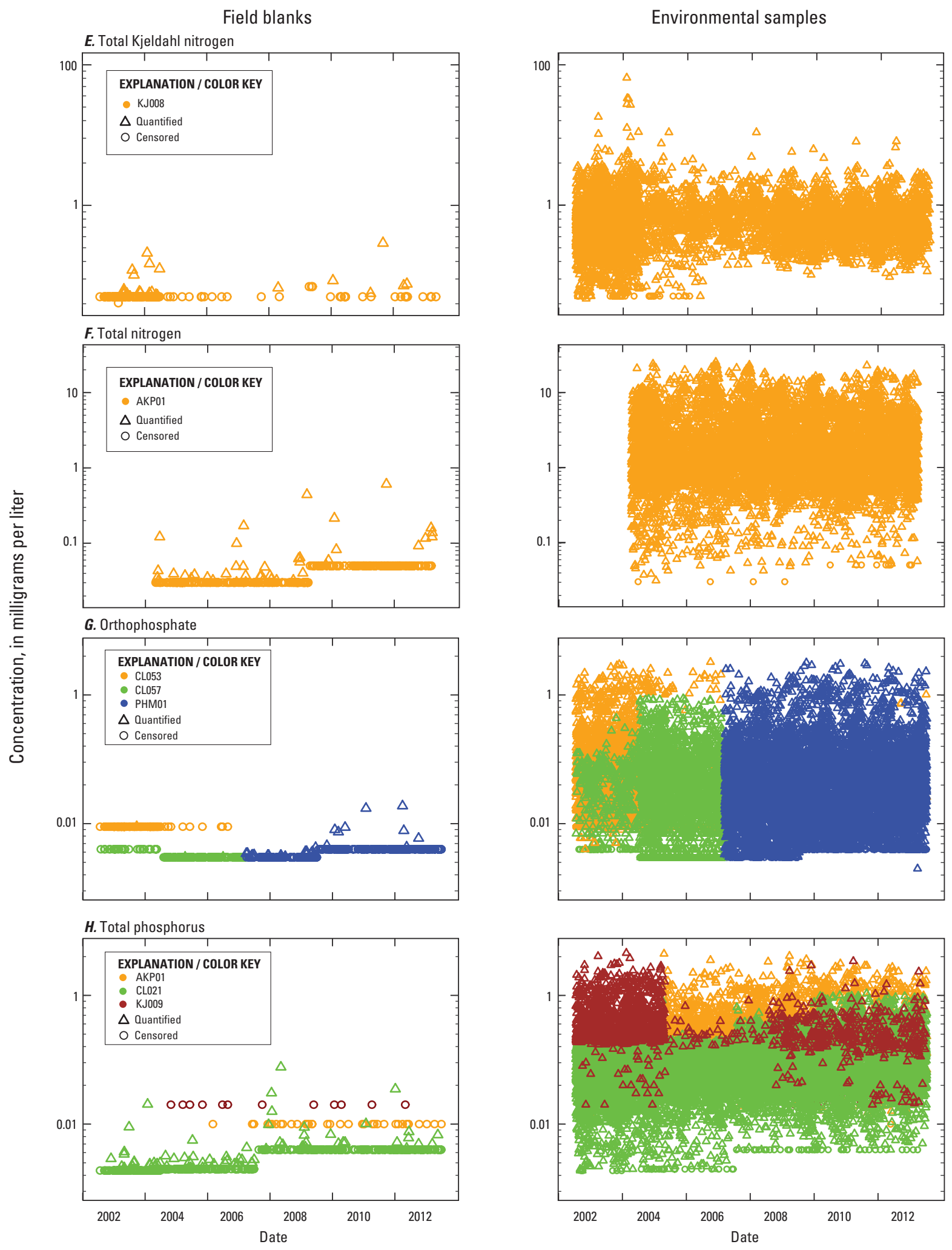

Figure 2. Concentrations, distinguished by analytical method, of $A$, ammonia; $B$, nitrite; $C$, nitrite plus nitrate;

$D$, particulate nitrogen; $E$, total Kjeldahl nitrogen; $F$, total nitrogen; $G$, orthophosphate; and $H$, total phosphorus in fieldblank and environmental surface-water samples from historical U.S. Geological Survey water-quality networks, water years 2002-12. Fewer than 0.1 percent of environmental samples may not be shown to optimize scaling. Analytical methods are described in table 2.-Continued 
A summary of nutrient field-blank results by analytical method, and by date for total nitrogen and total phosphorus (fig. 3), underscores where it might be important to evaluate potential contamination bias for populations of environmental samples separated by analytical method or by date. At the least, there is a clear separation between censor levels for all standard-level methods (orange fonts in fig. 3) and their low-level (green fonts) or single-method (blue or purple fonts) analytical alternatives and for date for total phosphorus.

Concentration summaries of nutrient field blanks highlighting detections by type of site, geography, and sampling network (fig. 4) round out the picture of nutrients in field blanks during cycle 2 . For ammonia, nitrite, and orthophosphate, data in figure 4 include only field blanks after the date that marked the end of concurrent low- and standard-level analytical methods. Total phosphorus (fig. $4 H$ ) includes only data analyzed by method CL021 because censor levels for the infrequently used methods AKP01 and KJ009 were higher. In general, no differences in detections of nutrients in field blanks between type of site or geography stand out as notable other than that more field blanks were taken at large inland sites and for sites in the 01 zone (North Atlantic slope basins) than other types of sites or geographic areas.

There appear to be some differences in patterns of fieldblank detections between the two largest historical USGS water-quality networks, NASQAN and NAWQA (fig. 4). The eight nutrient analytes presented in this report were on the routine NAWQA schedules, but TKN, total nitrogen, and total phosphorus were sampled infrequently by NASQAN. In a comparison of the NAWQA and NASQAN field blanks for each analyte using the nonparametric Peto-Prentice generalized Wilcoxon test for left-censored data (Helsel, 2012), the only analyte with significantly different data (at $\alpha=0.05$ ) between networks was PN (fig. $4 D$; keep in mind that for a given analyte, values for the large percentage of data that is censored [not shown directly in fig. 4, but implied as below the dotted horizontal lines] are the same for the two networks if censor levels are the same).

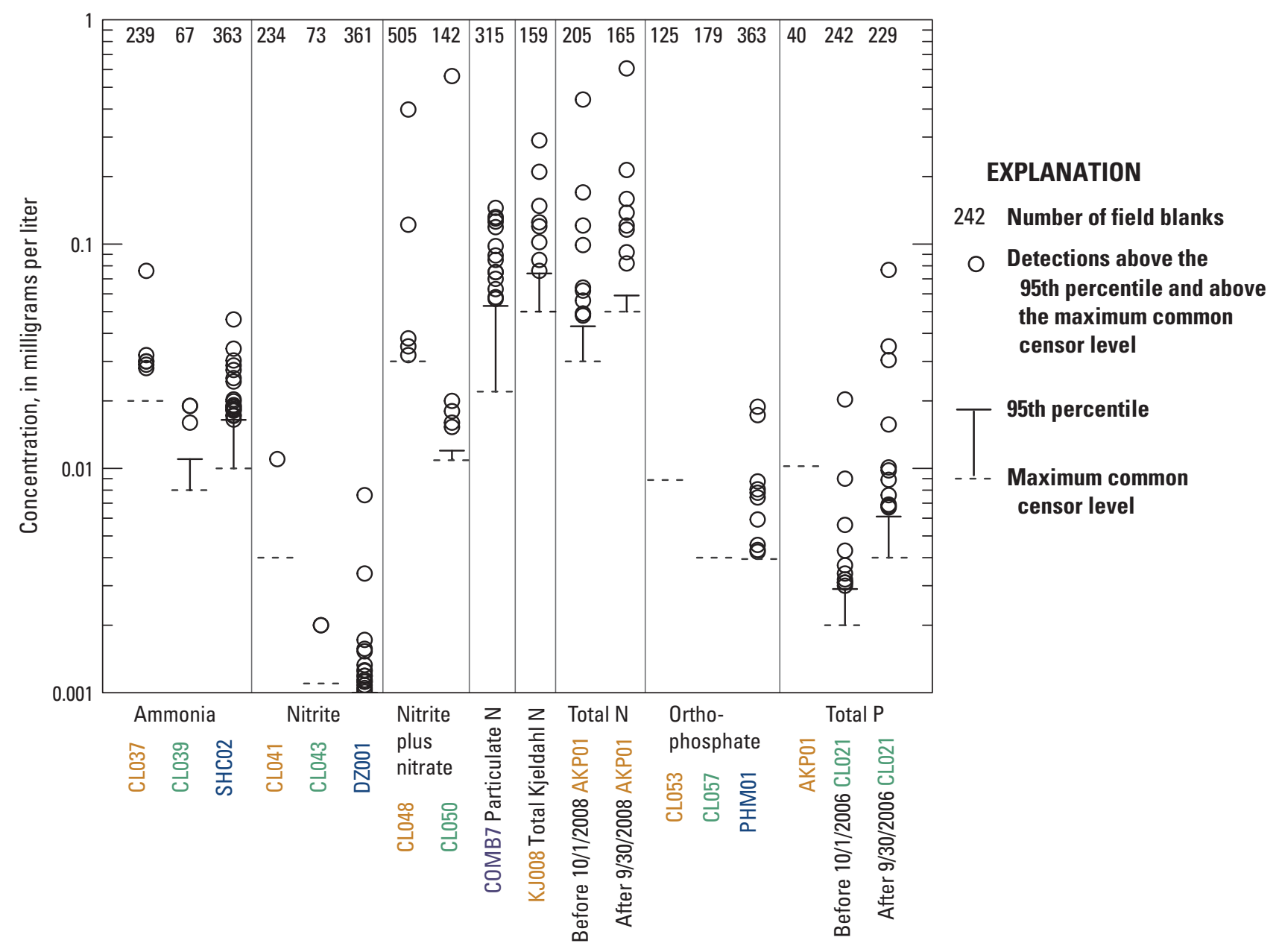

Figure 3. Distribution of nutrient analyte concentrations, split by analytical method and by date for some analytes, for field blanks associated with surface-water samples from historical U.S. Geological Survey water-quality networks, water years 2002-12. Field blanks with fewer than 40 samples analyzed by a particular method, such as RED01 and RED02 for nitrite plus nitrate and KJ009 for total phosphorus, are not shown. N, nitrogen; P, phosphorus. 
A. Ammonia (analyzed with method SHCO2)
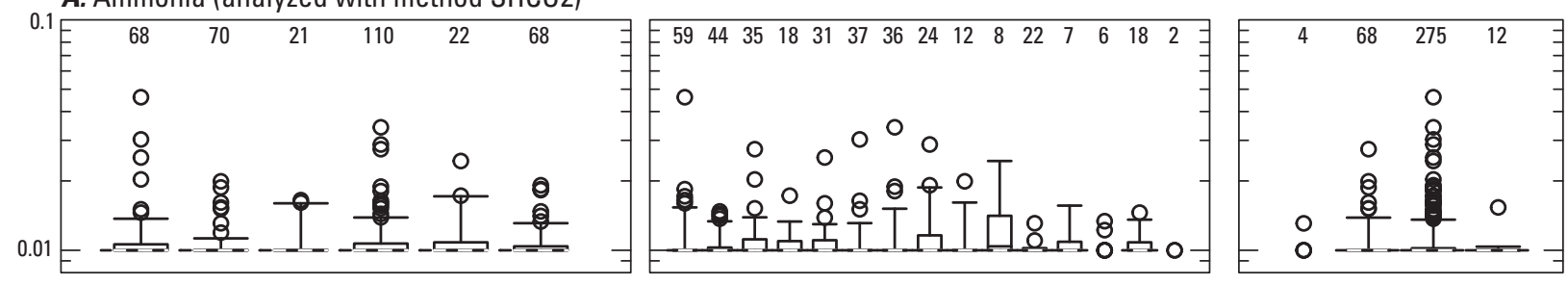

B. Nitrite (analyzed with method DZ001)
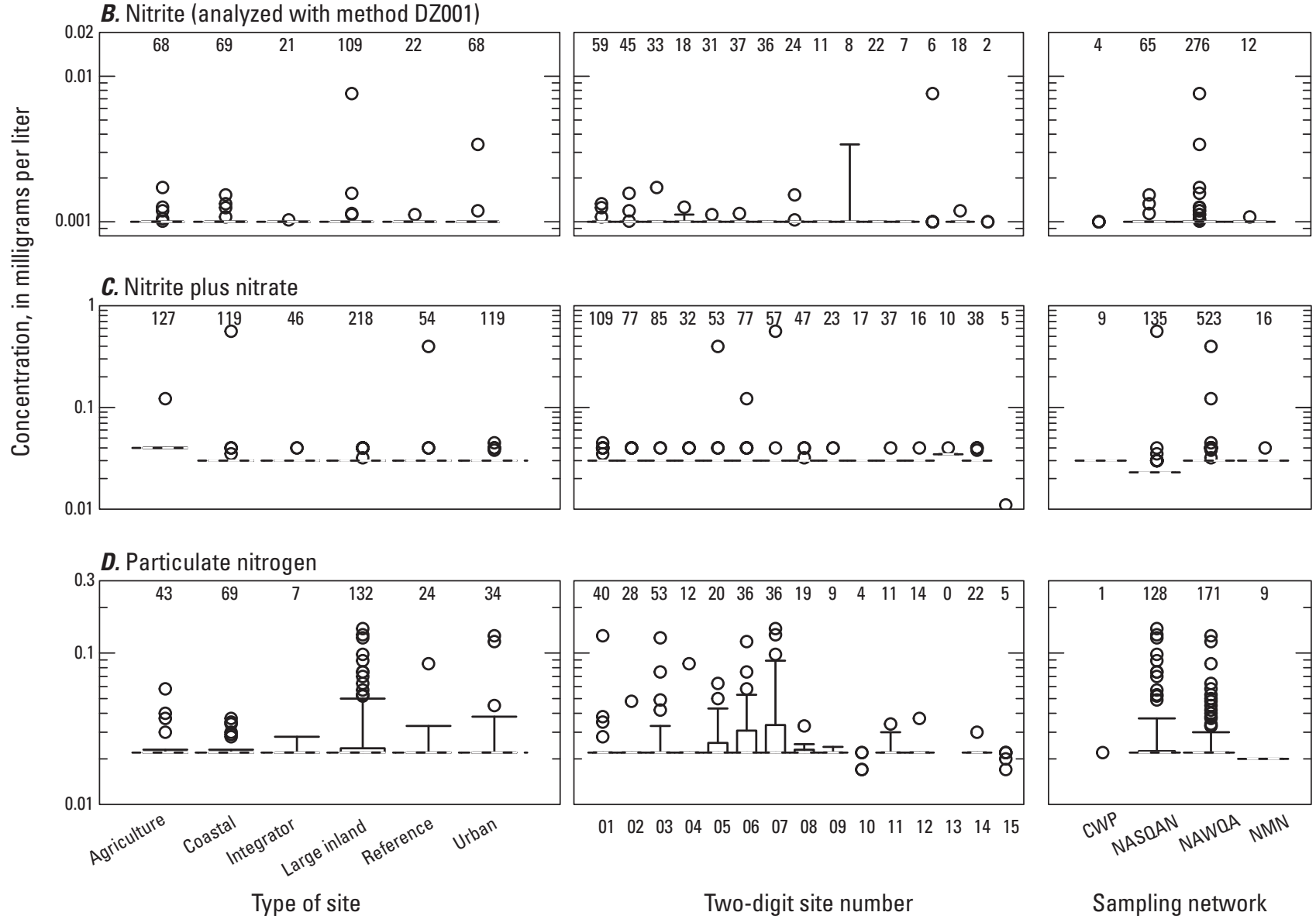

\section{EXPLANATION}

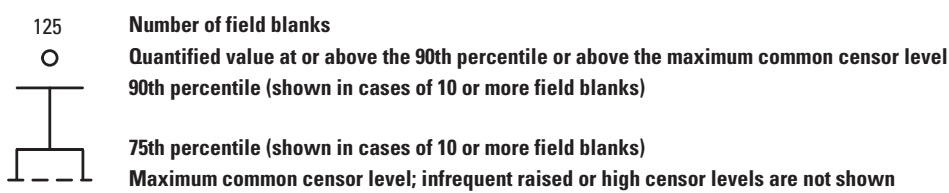

Figure 4. Concentration summaries of $A$, ammonia; $B$, nitrite; $C$, nitrite plus nitrate; $D$, particulate nitrogen; $E$, total Kjeldahl nitrogen; $F$, total nitrogen; $G$, orthophosphate; and $H$, total phosphorus in field blanks associated with surface-water samples from historical U.S. Geological Survey water-quality networks, grouped by type of site, first two digits of site number, and sampling network, water years 2002-12. The two-digit site number, representing major river basin, is a surrogate for geography. Historical water-quality networks are the National Water-Quality Assessment (NAWOA) Project, the National Stream Quality Accounting Network (NASQAN), the National Monitoring Network (NMN), and the Cooperative Water Program (CWP). The majority of sites were consolidated into the National Water Quality Network in 2015. 
E. Total Kjeldahl nitrogen
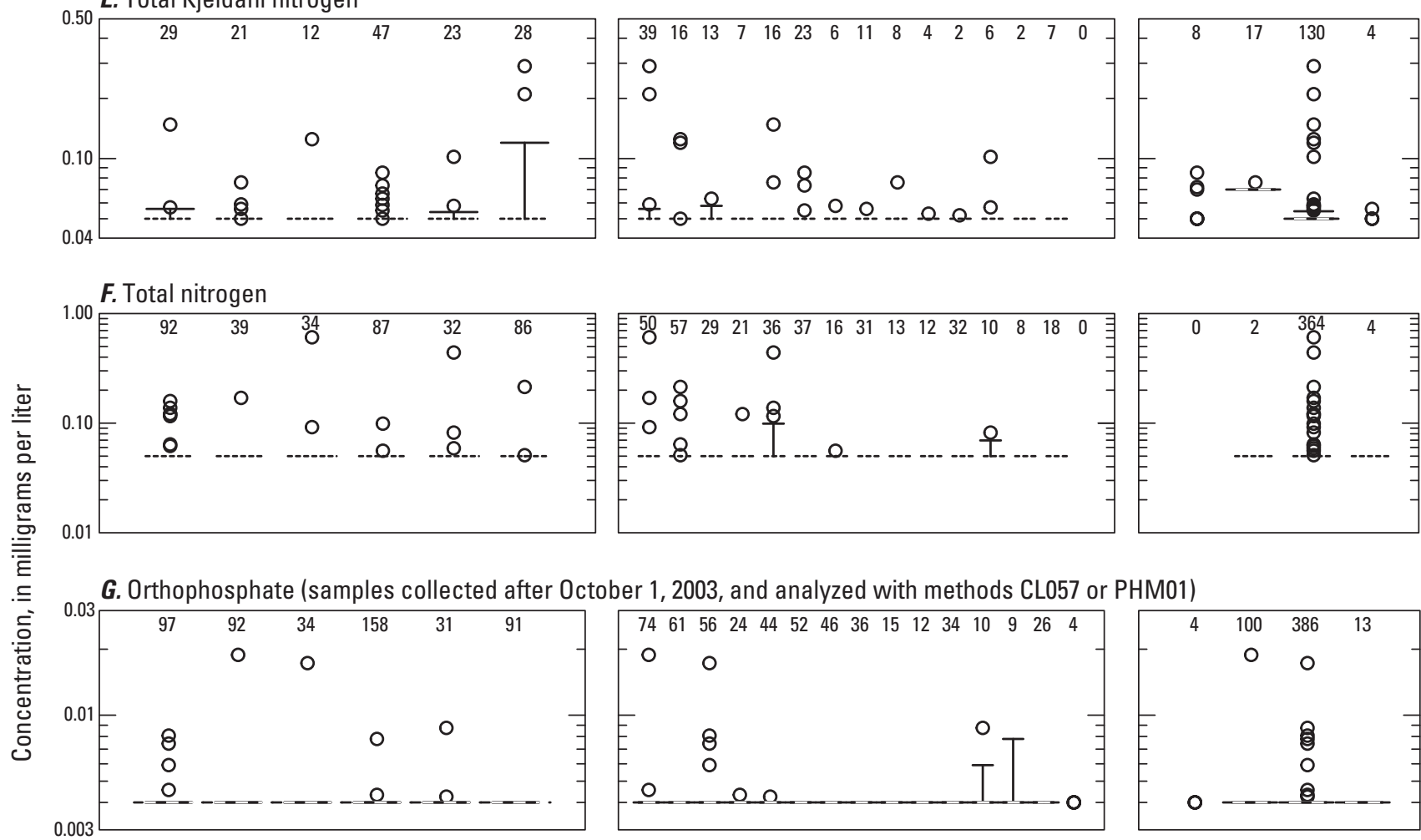

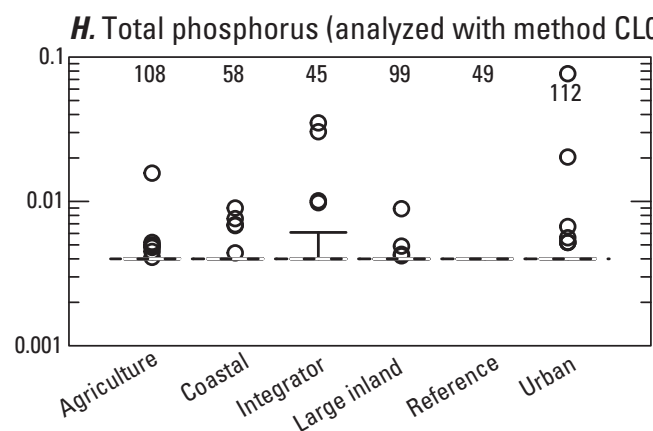

Type of site

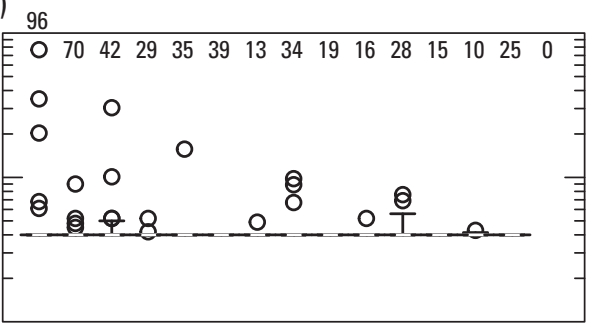

$\begin{array}{lllllllllllllll}01 & 02 & 03 & 04 & 05 & 06 & 07 & 08 & 09 & 10 & 11 & 12 & 13 & 14 & 15\end{array}$

Two-digit site number
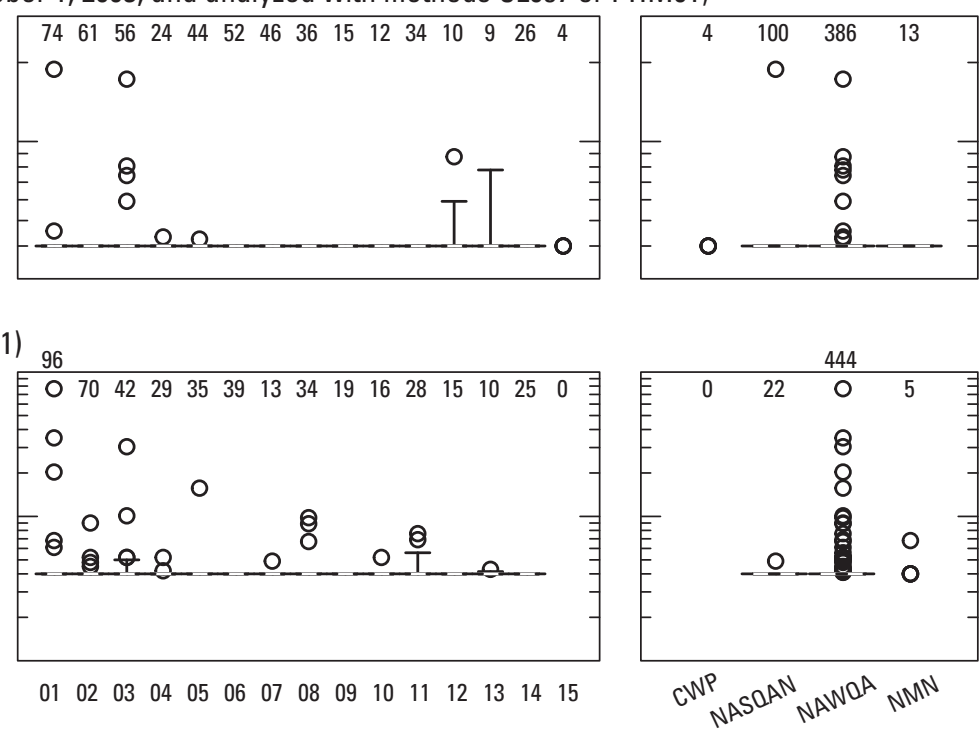

Sampling network

\section{EXPLANATION}

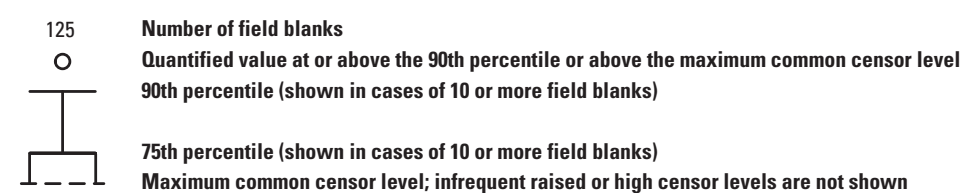

Figure 4. Concentration summaries of $A$, ammonia; $B$, nitrite; $C$, nitrite plus nitrate; $D$, particulate nitrogen; $E$, total Kjeldahl nitrogen; $F$, total nitrogen; $G$, orthophosphate; and $H$, total phosphorus in field blanks associated with surface-water samples from historical U.S. Geological Survey water-quality networks, grouped by type of site, first two digits of site number, and sampling network, water years 2002-12. The two-digit site number, representing major river basin, is a surrogate for geography. Historical water-quality networks are the National Water-Quality Assessment (NAWQA) Project, the National Stream Quality Accounting Network (NASQAN), the National Monitoring Network (NMN), and the Cooperative Water Program (CWP). The majority of sites were consolidated into the National Water Quality Network in 2015.-Continued 


\section{Pesticides}

Preliminary screening of field-blank results for pesticides with more than 10 quantified results by site type, geography, sampling network, and NWQL analytical schedule identified a potential bias. Of detections in field blanks, the largest percentages were found for the large inland site type, major river basin 07 (Lower Mississippi River Basin), the NASQAN sampling network, and NWQL analytical schedule 2010 (fig. 5).
Samples associated with NWQL schedule 2010 had a large percentage of detections ( 4 of 11 metolachlor and 4 of 12 atrazine field blanks, figs. $5 A$ and $5 B$ ), which is not unexpected because of extra challenges in keeping the processing environment clean while doing extractions in the field compared to the laboratory. However, without additional data, there is no way to verify that samples were contaminated during the processing step. Results associated with NWQL analytical schedule 2010 in appendix 2 are flagged and given a comment to indicate the probable bias.

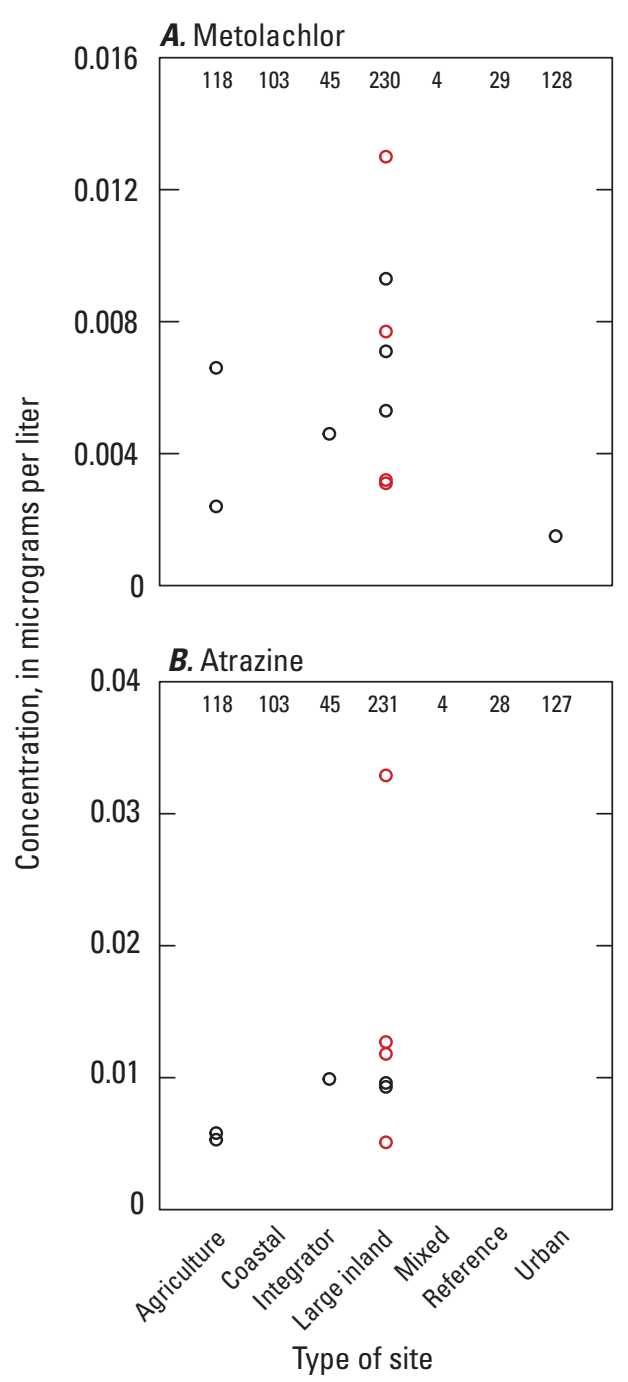

Type of site
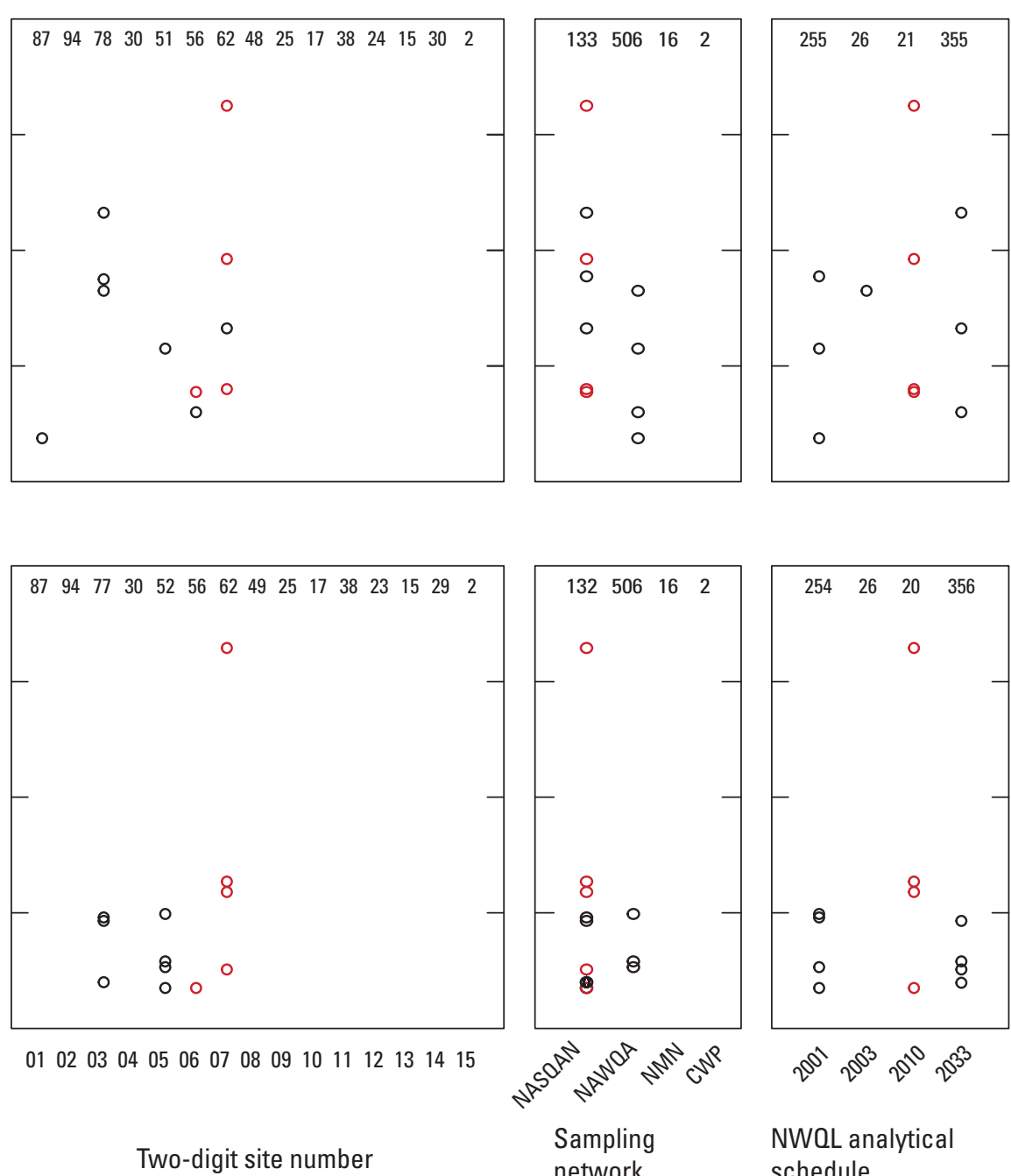

\section{EXPLANATION}

\footnotetext{
118 Number of values. Nondetects are included in this number but are not shown on plots

- Detection

- Detection in sample extracted in the field using NWOL analytical schedule 2010
}

Figure 5. Detections of $A$, metolachlor and $B$, atrazine in field blanks associated with surface-water samples from historical U.S. Geological Survey water-quality networks, grouped by type of site, first two digits of site number, sampling network, and National Water Quality Laboratory (NWOL) analytical schedule, water years 2002-12. The two-digit site number, representing major river basin, is a surrogate for geography. Historical water-quality networks are the National Water-Quality Assessment (NAWQA) Project, the National Stream Quality Accounting Network (NASQAN), the National Monitoring Network (NMN), and the Cooperative Water Program (CWP). The majority of sites were consolidated into the National Water Quality Network in 2015. 
For the 40 pesticides summarized in this report, the number of field blanks collected during water years 2002-12 ranged from 571 for 3 of the fipronil degradates to 666 for carbaryl (table 5), corresponding to 6 percent of the number of environmental samples collected in all cases. Twenty-six pesticides had no detections in field blanks, and 4 pesticides had only 1 detection. Atrazine and metolachlor, two of the most widely used pesticides during the period, had the highest number of detections (12 and 11) in field blanks; they also had more than 50 percent detections in environmental samples. Most detections of atrazine and metolachlor in field blanks were in spring or early summer, corresponding to the time of year when these agricultural herbicides are typically applied to corn and soybean fields (Gilliom and others, 2006). Simazine, prometon, and deethylatrazine, also with more than 50 percent detections in environmental samples, had three or fewer detections in field blanks. Dacthal, with a relatively high number (6) of detections in field blanks, had less than 10 percent detections in environmental samples. Most pesticides had 0 or 1 detection in field blanks and also a small percentage of detections in environmental samples.

As with nutrients, time-series plots of pesticides in field blanks (fig. 6) were characterized by changing censor levels over the years, except for atrazine, which was censored at 0.004 microgram per liter $(\mu \mathrm{g} / \mathrm{L})$ throughout the study period (fig. 6C). Unlike nutrients, however, detections for pesticides occurred above and below censor levels; those below censor levels were automatically given an "E" remark code before October 1, 2010, and a " $t$ " remark code after that date.

\section{Assessment of Contamination and Implications for the Interpretation of Environmental Data}

Three questions are addressed in this section: what is the potential contamination bias, which environmental samples might be affected, and how might bias affect those environmental samples? UCLs are compared to important concentrations based on human health or aquatic life. Critical concentrations for nutrients include background concentrations at undisturbed sites, aquatic-life criteria, and drinking-water standards set by the U.S. Environmental Protection Agency (EPA). For pesticides, critical concentrations are human-health benchmarks established by the EPA and USGS and aquatic-life benchmarks established by the EPA. These are, however, only a subset of criteria that might be of interest. Other concentrations could be important for reasons specific to individuals or organizations. Concentrations besides those listed in tables in this section that are important to the data user can be evaluated by using similar techniques.

\section{Nutrients}

Detection frequencies of nutrients in environmental samples are at least 42 percent (for ammonia analyzed with method CL037), although many are much higher, up to 100 percent for TKN and total nitrogen (table 4). A lower limit for expected detection frequencies in environmental samples can be established by subtracting the 95-percent UCL for percent detections seen in the respective field blanks (table 4), which range from 3 (for orthophosphate method CL057) to 51 (for nitrite plus nitrate method RED02) from the observed detection frequencies. For example, the range of expected detection frequencies for orthophosphate in environmental samples analyzed with method PHM01 is 84 to 96 . The median adjustment to nutrient analytes for detection frequency is 16 percent.

Several measures of potential contamination bias for environmental samples, including the largest potential contamination for the 95th percentile, the maximum concentration potentially affected, and the percentage of samples that might be affected, are shown in table 6 , along with drinkingwater standards and concentrations critical to aquatic-life or impairment risk. Included for comparisons where available are background concentrations of nutrients from 110 stream sites across the United States with minimal or no development (Dubrovsky and others, 2010). Criteria for nutrients related to eutrophication are not provided because the EPA's strategy (as of 2015) for nutrient enrichment in streams is for States and tribes to develop individualized numeric criteria in recognition of regional differences (U.S. Environmental Protection Agency, 2000). Recent guidance from EPA encourages States to develop joint nitrogen and phosphorus criteria because of their interconnectedness in processes affecting eutrophication (U.S. Environmental Protection Agency, 2015a).

The UCL plots for nutrients in figure 7 show that the distributions of field blanks are typically one to two orders of magnitude less than the distributions of environmental samples. Determined from the lowest percentile plotted for the 95-percent UCL for field blanks in figure $7 A$ for each color (nondetections are used to determine percentiles but are not shown on the graphs), potential ammonia contamination is estimated, with at least 95-percent confidence, to be less than detection up to the 96th percentile for samples analyzed with method CL037, the 89th percentile for samples analyzed with method CL039, and the 72nd percentile for samples analyzed with method SHC02. Potential contamination also is estimated to exceed $0.02,0.019$, or $0.0187 \mathrm{mg} / \mathrm{L}$ in no more than 5 percent of all samples analyzed with methods CL037, CL039, or SHC02 (table 4 and repeated in table 6) and to exceed $0.076,0.019$, or $0.0462 \mathrm{mg} / \mathrm{L}$ (table 4) in no more than 1 percent of samples, although contamination could be higher in the remaining 5 or 1 percent of samples. About 95 percent 
Table 5. Number and detection rates of field-blank and environmental samples and 99-percent upper confidence limits for percent detections and concentrations in field blanks, for pesticides in surface-water samples from historical U.S. Geological Survey waterquality networks, water years 2002-12.

$[\mu \mathrm{g} / \mathrm{L}$, microgram per liter; $<$, less than]

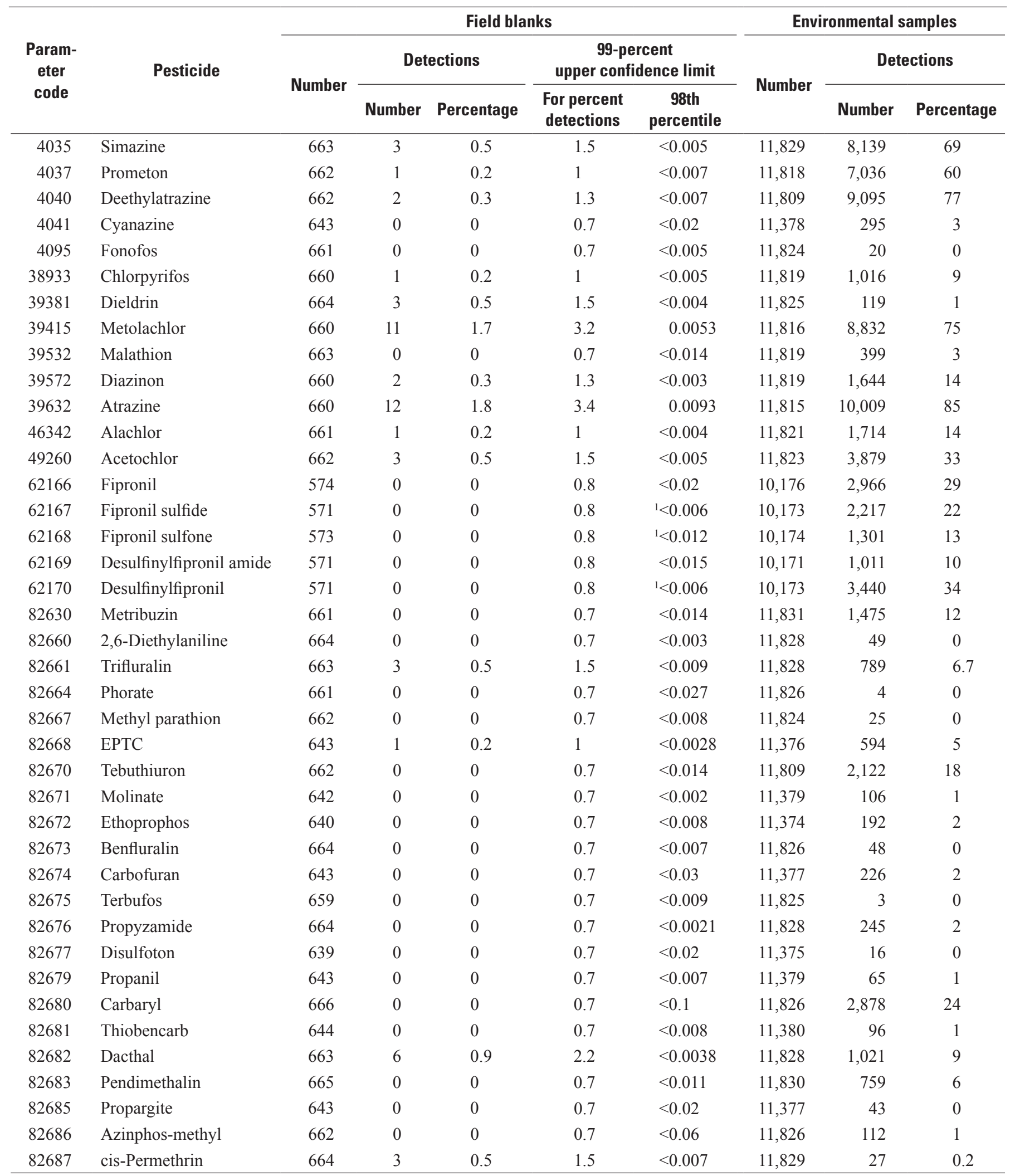

${ }^{1}$ Excludes two results with raised reporting levels. 

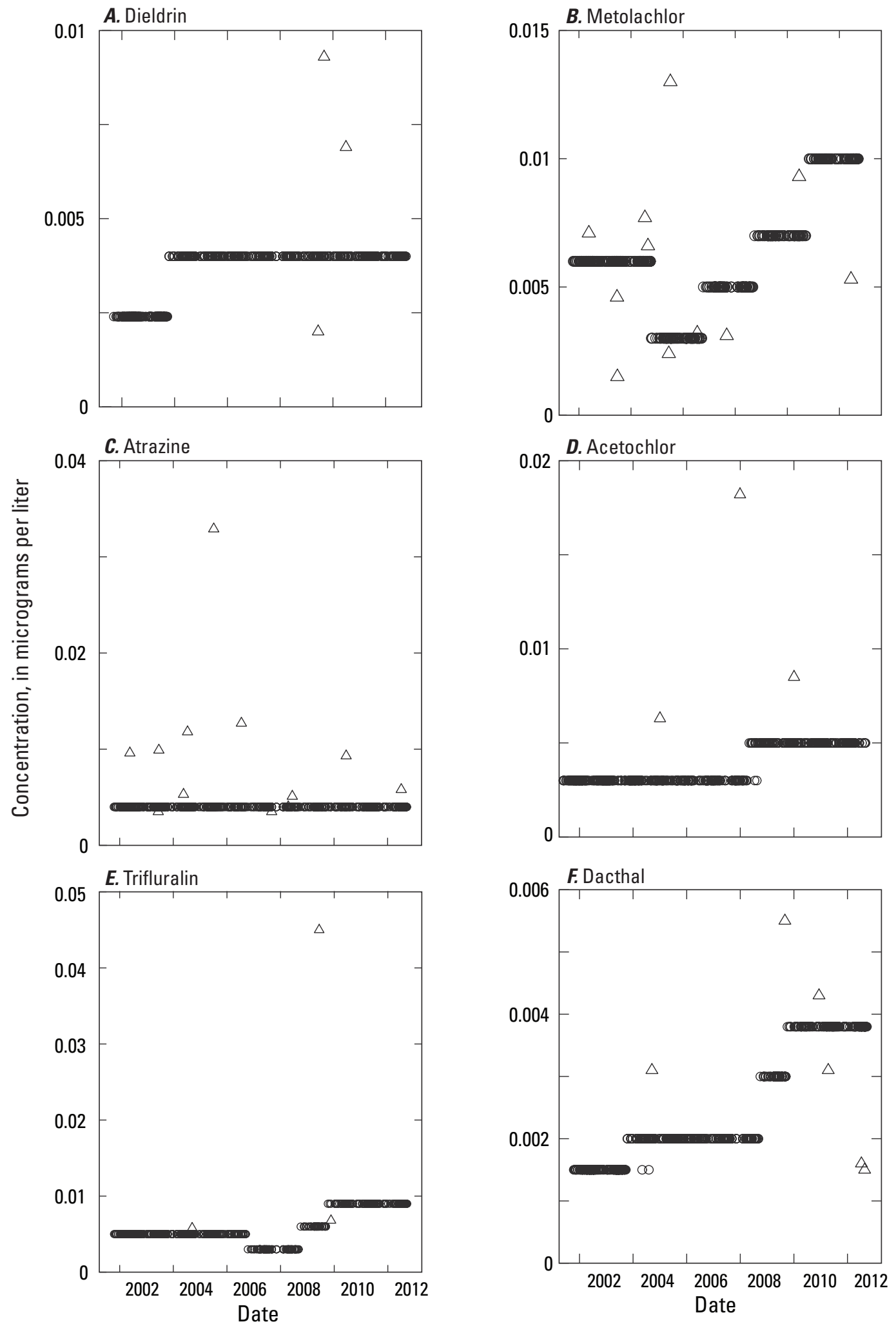

Figure 6. Concentrations of $A$, dieldrin; $B$, metolachlor; $C$, atrazine; $D$, acetochlor; $E$, trifluralin; and $F$, Dacthal in field blanks associated with surface-water samples from historical U.S. Geological Survey water-quality networks, water years 2002-12. Triangles are detections and circles are censored values. 
Table 6. Potential contamination bias for environmental samples and critical or background values for relating to environmental samples.

[mg/L, milligram per liter; mg TAN/L, milligram of total ammonia nitrogen per liter; <, less than; --, not applicable]

\begin{tabular}{|c|c|c|c|c|c|c|}
\hline \multirow[b]{2}{*}{ Nutrient analyte } & \multirow[b]{2}{*}{$\begin{array}{l}\text { Method } \\
\text { abbrevia- } \\
\text { tion } \\
\text { (defined in } \\
\text { table 2) }\end{array}$} & \multicolumn{3}{|c|}{$\begin{array}{l}\text { Potential contamination bias for } \\
\text { environmental samples }\end{array}$} & \multicolumn{2}{|c|}{ Critical or background value ${ }^{1}$} \\
\hline & & $\begin{array}{l}\text { Largest } \\
\text { potential con- } \\
\text { tamination } \\
\text { for the } 95 \text { th } \\
\text { percentile } \\
\text { (mg/L) }\end{array}$ & $\begin{array}{l}\text { Maximum } \\
\text { affected } \\
\text { concentra- } \\
\text { tion }{ }^{2} \\
\text { (mg/L) }\end{array}$ & $\begin{array}{c}\text { Percent } \\
\text { poten- } \\
\text { tially } \\
\text { affected }\end{array}$ & Description & $\begin{array}{l}\text { Concentration } \\
\text { (mg/L) }\end{array}$ \\
\hline \multirow{2}{*}{ Ammonia } & CL039 & 0.019 & 0.19 & 9.2 & & $\begin{array}{l}\text { Acute: } 0.27-51 \mathrm{mg} \text { TAN/L } \\
\text { Chronic: } 0.08-4.9 \mathrm{mg} \text { TAN/L }\end{array}$ \\
\hline & $\mathrm{SHC02}$ & 0.0187 & 0.187 & 26.9 & Background $^{6}$ & 0.025 \\
\hline \multirow[t]{2}{*}{ Nitrite } & CL041 & $<0.004$ & $<0.04$ & 2.6 & Drinking-water standard ${ }^{7}$ & 1 \\
\hline & CL043 & $<0.0011$ & $<0.011$ & 0 & & \\
\hline \multirow{2}{*}{ Nitrite plus nitrate } & RED01 & 0.0449 & 0.449 & 2.2 & Background $^{6}$ & 0.24 \\
\hline & RED02 & 0.0158 & 0.16 & 14.8 & & \\
\hline Particulate nitrogen & COMB7 & 0.070 & 0.70 & 21.2 & -- & -- \\
\hline Total Kjeldahl nitrogen & KJ008 & 0.120 & 1.20 & 16.5 & -- & -- \\
\hline \multirow[t]{2}{*}{ Total nitrogen } & AKP01 & 0.064 & 0.64 & 1.1 & Impairment risk $^{8}$ & $0.275-1.5$ \\
\hline & & & & & Background $^{6}$ & 0.58 \\
\hline \multirow[t]{2}{*}{ Orthophosphate } & CL053 & $<0.009$ & $<0.09$ & 1.5 & Impairment risk $^{8}$ & $0.01-0.06^{9}$ \\
\hline & CL057 & $<0.004$ & $<0.04$ & 0 & & \\
\hline
\end{tabular}

${ }^{1}$ Multiple items in these columns apply to the analyte irrespective of analytical method.

${ }^{2}$ Value is 10 times the 95-percent upper-confidence limit for the 95th percentile of field blanks (Mueller and Titus, 2005).

${ }^{3}$ Pertains to samples collected before October 1, 2006.

${ }^{4}$ Pertains to samples collected after September 30, 2006.

${ }^{5}$ U.S. Environmental Protection Agency recommends an acute criterion magnitude of $17 \mathrm{mg}$ TAN/L at pH 7 and 20 degrees Celsius for a 1-hour average duration, not to be exceeded more than once every 3 years on average, and a chronic criterion magnitude of $1.9 \mathrm{mg}$ TAN/L at pH 7 and 20 degrees Celsius for a 30-day average duration, not to be exceeded more than once every 3 years on average (U.S. Environmental Protection Agency, 2013a). These criteria are $\mathrm{pH}$ and temperature dependent. Acute concentrations range from 0.27 to $51 \mathrm{mg}$ TAN/L and chronic concentrations range from 0.08 to $4.9 \mathrm{mg}$ TAN/L over pH values ranging from 6.5 to 9 and temperatures ranging from 0 to 30 degrees Celsius.

${ }^{6}$ Dubrovsky and others (2010), table 4-1.

${ }^{7}$ Maximum contaminant level (U.S. Environmental Protection Agency, 2009).

${ }^{8}$ Literature values of impairment risk due to nuisance algae growth or eutrophication (U.S. Environmental Protection Agency, 2000).

${ }^{9}$ Concentration range is expressed for soluble reactive phosphorus. 
of environmental samples analyzed with method CL037 have concentrations less than the maximum (less than $0.2 \mathrm{mg} / \mathrm{L}$ ) that might be affected (fig. $7 \mathrm{~A}$, orange dot on the environmental concentration curve; table 6); similarly, 84 or 96 percent of environmental samples analyzed with methods CL039 or SHC02 have concentrations less than the maximums that are potentially affected. Pooling these possibilities of contamination together, $3.8,{ }^{10} 9.2$, or 26.9 percent of all environmental samples that were analyzed with methods CL037, CL039, or SHC02, respectively, are potentially affected by ammonia contamination (table 6). The nearly 27 percent of environmental samples analyzed with method SHC02 that likely had some ammonia contamination pertains to surface-water results from 2007 through 2012.

Because the minimum aquatic-life criterion for acute effects for ammonia for all $\mathrm{pH}$ and temperature combinations, $0.27 \mathrm{mg} / \mathrm{L}$ (table 6), is greater than the maximum concentrations of environmental samples that are potentially affected by contamination, ammonia contamination is unlikely to affect the comparison between environmental samples and that criterion. In contrast, the range (from 0.08 to $4.9 \mathrm{mg} / \mathrm{L}$ ) of aquaticlife criteria for chronic effects for combinations of high $\mathrm{pH}$ and high temperature includes some values less than 0.2, 0.19 , or $0.187 \mathrm{mg} / \mathrm{L}$. The combination of high $\mathrm{pH}$ and high temperature necessary for the lower ammonia criteria to go into effect (for example, where $\mathrm{pH}$ is at least 8.5 and temperature is at least 29 degrees Celsius, or where $\mathrm{pH}$ is at least 9.0 and temperature is at least 16 degrees Celsius) is rarely found in streams. Only about 2 percent of stream samples included in the dataset of samples analyzed for this report have those combinations of $\mathrm{pH}$ and temperature. Thus, under the very rare conditions found at the minimum of the range for the aquaticlife criteria for chronic effects, contamination is likely to have affected no more than $0.1,0.2$, or 0.5 percent ( 2 percent of 3.8 , 9.2, or 26.9 percent) of environmental samples, depending on the analytical method. Although rare, contamination greater than the 95th percentile values of less than $0.02,0.019$, or $0.0187 \mathrm{mg} / \mathrm{L}$ could account for more than 23 to 25 percent of measured ammonia concentrations.

Figure $7 B$ shows that potential nitrite contamination is estimated, with at least 95-percent confidence, to be less than detection up to the 97 th percentile of samples analyzed with method CL041, the 100th percentile (nothing to show in fig. $7 B$ ) of samples analyzed with method CL043, and the 94th percentile of samples analyzed with method DZ001 (the most commonly used method for nitrite during the period). Potential contamination also is estimated to exceed 0.004 , 0.0011 , or $0.0011 \mathrm{mg} / \mathrm{L}$ in no more than 5 percent of all samples analyzed with methods CL041, CL043 or DZ001 (tables 4, 6) and to exceed $0.011,0.0011$, or $0.0034 \mathrm{mg} / \mathrm{L}$

\footnotetext{
${ }^{10}$ Using the example of samples analyzed with method CL037, the net percentage affected is the result of multiplying the percentage of environmental samples that might be affected by contamination ( 4 percent, calculated as 100 percent minus the 96 percent that have contamination less than detection) by the 95 percent of samples that are less than the maximum concentration $(0.2 \mathrm{mg} / \mathrm{L})$ potentially affected. The product of 0.04 times 0.95 is 3.8 percent.
}

in no more than 1 percent of samples analyzed by the listed methods. Contamination could be higher in the remaining 5 or 1 percent of all samples. About 87 percent of environmental samples analyzed with method CL041 have concentrations less than the maximum (less than $0.04 \mathrm{mg} / \mathrm{L}$ ) that might be affected (table 6), and 56 or 55 percent of environmental samples analyzed with methods CL043 or DZ001 have concentrations less than the maximums (less than 0.011 and $0.011 \mathrm{mg} / \mathrm{L}$ ) that are potentially affected. The net result is that very few environmental samples, 2.6, 0 , or 3.3 percent of those analyzed with methods CL041, CL043, or DZ001, respectively, are potentially affected by contamination. For context, potential nitrite contamination affected no more than 2.6 percent of environmental samples collected between 2002 and 2006 and affected about 3.3 percent of samples collected between 2007 and 2012. Because each maximum potentially affected nitrite concentration is far less, by at least a factor of 25, than the EPA maximum contaminant level (MCL) of $1 \mathrm{mg} / \mathrm{L}$ for nitrite (table 6), the chance is minimal that contamination affects the assessment of environmental concentrations relative to the MCL for drinking water.

Potential nitrite plus nitrate contamination for cycle 2 samples collected through 2011, with 95-percent confidence, is less than detection for 98 percent of samples analyzed with method CL048 (the most commonly used method during the period) and is less than detection for 78 percent of those analyzed with methods CL050 (fig. 7C). For samples collected during 2012, potential nitrite plus nitrate contamination was less than detection for 93 (method RED01) or 41 (method RED02) percent of samples. Potential contamination is estimated to exceed 0.03 (or 0.038 ) $\mathrm{mg} / \mathrm{L}$ in no more than 5 or 1 percent of samples analyzed with method CL048, to exceed 0.016 (or 0.5611 ) $\mathrm{mg} / \mathrm{L}$ in no more than 5 or 1 percent of samples analyzed with method CL050, to exceed $0.0449 \mathrm{mg} / \mathrm{L}$ in no more than 5 or 1 percent of samples analyzed with method RED01, and to exceed $0.0158 \mathrm{mg} / \mathrm{L}$ in no more than 5 or 1 percent of samples analyzed with method RED02 (tables 4, 6). About 20 percent of environmental samples analyzed with method CL048 (off the x-axis scale in fig. 7C) have concentrations less than the maximum (less than $0.3 \mathrm{mg} / \mathrm{L}$, table 6) that might be affected by contamination; 33,32 , and 36 percent of samples analyzed with methods CL050, RED01, and RED02 have concentrations less than the maximums $(0.16,0.449$, $0.16 \mathrm{mg} / \mathrm{L}$ ) potentially affected. About 0.4 and 7.3 percent of environmental samples collected from 2002 through 2011 and analyzed with methods CL048 and CL050, respectively, are potentially affected by contamination, as are 2.2 and 14.8 percent of samples analyzed with methods RED01 and RED02 during 2012.

Because the maximum potentially affected concentrations for nitrite plus nitrate regardless of analytical method are much less than the MCL of $10 \mathrm{mg} / \mathrm{L}$, there is minimal likelihood that contamination would interfere with interpretations relative to MCLs for drinking water. Contamination of environmental samples analyzed by all methods except RED01 might affect concentrations near background levels of 

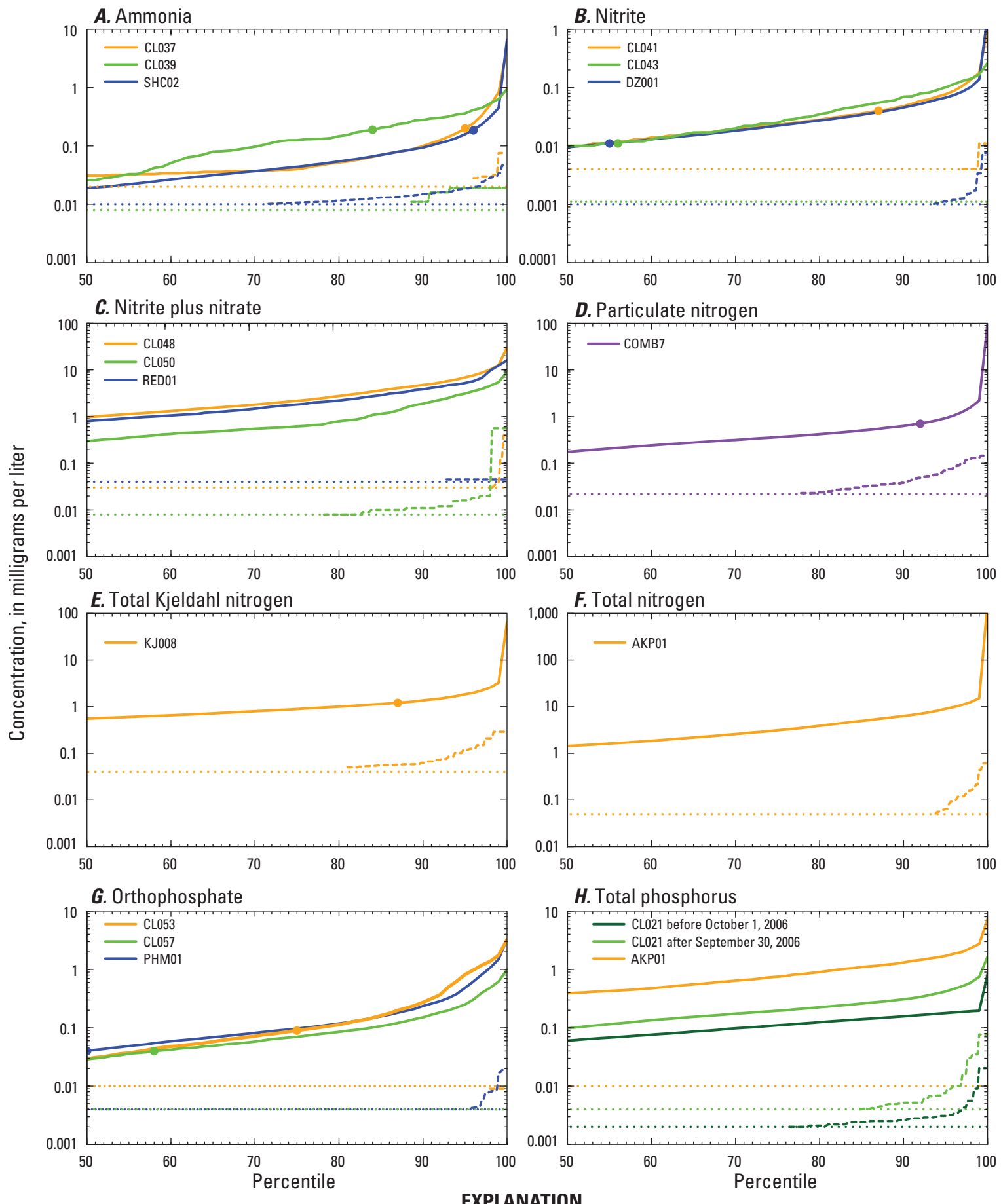

\section{EXPLANATION}

Environmental concentrations, variously colored

$\longrightarrow$ Environmental concentration that equals 10 times the 95th percentile for blanks, variously colored

95-percent upper confidence limit concentrations

for specified percentile for field blanks, variously colored

Maximum common censor level, variously colored

PHM01 Line color and plot legend corresponds to analytical method defined in table 2

Figure 7. Distribution of concentrations of $A$, ammonia; $B$, nitrite; $C$, nitrite plus nitrate; $D$, particulate nitrogen; $E$, total Kjeldahl nitrogen; $F$, total nitrogen; $G$, orthophosphate; and $H$, total phosphorus in field-blank and environmental surface-water samples from historical U.S. Geological Survey water-quality networks, water years 2002-12. Nondetections are used to determine percentiles but are not shown on the graphs. 
nitrite plus nitrate in surface water $(0.24 \mathrm{mg} / \mathrm{L})$; however, this possibility of contamination only pertains to at most $0.4,7.3$, or 14.8 percent of environmental samples.

Figure $7 D$ shows that potential contamination from $\mathrm{PN}$ is estimated, with at least 95-percent confidence, to be less than detection up to the 77 th percentile of all samples. Potential contamination also is estimated to exceed $0.07 \mathrm{mg} / \mathrm{L}$ in no more than 5 percent of all samples (tables 4,6 ) and to exceed $0.132 \mathrm{mg} / \mathrm{L}$ in no more than 1 percent of samples, although it could be higher in the remaining 5 or 1 percent of samples. About 92 percent of environmental samples have concentrations less than the maximum $(0.7 \mathrm{mg} / \mathrm{L})$ that might be affected (table 6; fig. 7D). Although contamination potentially affects 21.2 percent of environmental samples analyzed for $\mathrm{PN}$, the absence of drinking-water standards and aquatic-life criteria for this substance can allay concerns about contamination interfering with sample interpretation.

With 95-percent confidence, potential contamination from TKN is estimated to be less than detection for 81 percent of all samples (fig. $7 E$ ), to exceed $0.12 \mathrm{mg} / \mathrm{L}$ in no more than 5 percent of samples (tables 4,6 ), and to exceed $0.29 \mathrm{mg} / \mathrm{L}$ in no more than 1 percent of samples. About 87 percent of environmental samples have concentrations less than the maximum concentration $(1.2 \mathrm{mg} / \mathrm{L}$, table 6$)$ that might be affected. Contamination from TKN thus potentially affects 16.5 percent of environmental samples; however, as with $\mathrm{PN}$, there are no drinking-water standards or aquatic-life criteria for TKN that might need to be considered for the interpretation of sample results.

Potential contamination from total nitrogen is estimated to be less than detection for 94 percent of environmental samples (fig. $7 F$ ), to exceed $0.064 \mathrm{mg} / \mathrm{L}$ in no more than 5 percent of samples (tables 4,6 ), and to exceed $0.441 \mathrm{mg} / \mathrm{L}$ in no more than 1 percent of samples. Contamination could be higher than these concentrations in the remaining 5 or 1 percent of samples. Approximately 18 percent of environmental samples (off the scale in fig. $7 F$ ) have concentrations less than the maximum concentration $(0.64 \mathrm{mg} / \mathrm{L}$, table 6$)$ that might be affected. As a whole, contamination from total nitrogen potentially affects 1.1 percent ( 6 percent of 18 percent) of all environmental samples. Qualification of environmental results for this small percentage potentially affected by contamination is needed because the concentration of $0.64 \mathrm{mg} / \mathrm{L}$ falls within the range of concentrations for impairment risk and is greater than background levels for total nitrogen (table 6).

Potential contamination from orthophosphate is estimated, with 95-percent confidence, to be less than detection up to the 98th percentile of all samples analyzed with method CL053, the 100th percentile for samples analyzed with method CL057, and the 96th percentile for samples analyzed with method PHM01 (fig. 7G). For samples analyzed with methods CL053, CL057, and PHM01, potential contamination is estimated to exceed the respective censor levels in no more than 5 percent of all samples (tables 4,6 ) and to exceed 0.009 , less than 0.004 , or $0.0173 \mathrm{mg} / \mathrm{L}$ in no more than 1 percent of samples, although it might be higher in the remaining 5 or 1 percent of samples. About 75 percent of environmental samples analyzed with method CL053 have concentrations less than the maximum (less than $0.09 \mathrm{mg} / \mathrm{L}$ ) that might be affected (table 6), and 58 or 50 percent of environmental samples analyzed with methods CL057 or PHM01 have concentrations less than the maximums (less than $0.04 \mathrm{mg} / \mathrm{L}$ for each) that are potentially affected. Small percentages of environmental samples, $1.5,0$, or 2.0 percent of those analyzed with methods CL053, CL057, or PHM01 respectively, are potentially affected by contamination. Even so, environmental samples need to be qualified before they are compared with impairment risks or background levels because concentrations that could be contaminated are higher than numeric criteria for orthophosphate.

Potential contamination from total phosphorus, for samples analyzed with method CL021 (fig. $7 H$ ), is estimated to be less than detection for 76 percent of samples in the first part of the period (before October 1, 2006), less than detection for 85 percent of samples in the last part of the period (after September 30, 2006), and less than detection for 100 percent of samples analyzed with method AKP01. Potential contamination also is expected to exceed 0.0031 and $0.0076 \mathrm{mg} / \mathrm{L}$ for samples analyzed with method CL021 and in the first and last parts of the period, respectively, in no more than 5 percent of all samples (tables 4,6 ) and to exceed 0.0203 and $0.0767 \mathrm{mg} / \mathrm{L}$ in no more than 1 percent of samples. Concentrations, however, might be higher in the remaining 5 or 1 percent of samples. For samples analyzed with method CL021, about 23 percent of environmental samples in the first part of the period have concentrations less than the maximum $(0.031 \mathrm{mg} / \mathrm{L})$ potentially affected by contamination (table 6$)$, and 42 percent in the last part of the period have concentrations less than the maximum $(0.076 \mathrm{mg} / \mathrm{L})$. The net result is that 5.5 or 6.3 percent of environmental samples from the first and last parts of the period, respectively, and analyzed with method CL021, are potentially affected by contamination. Because the maximum potentially affected concentrations are within the range of impairment risk for total phosphorus and are near or above the background level, environmental samples analyzed with method CL021 should be qualified to address this potential for contamination bias.

Although potential contamination for most of the nutrients that were analyzed could affect only a small percentage of environmental samples, for those with concentrations within or near the range of critical or background values, the amount of contamination could be substantial. Nutrients in this category with potentially large amounts of contamination for a small percentage of samples near critical values are ammonia, nitrite plus nitrate methods (all methods except RED01), total nitrogen, orthophosphate, and total phosphorus. For example, at concentrations at the low end of impairment risk for total nitrogen, contamination greater than the 95 th percentile value of $0.064 \mathrm{mg} / \mathrm{L}$ could account for more than 23 percent $(0.064$ divided by $0.275 \mathrm{mg} / \mathrm{L}$ ) of the measured ammonia concentration that would indicate impairment. At the low end of the range of impairment risk for orthophosphate $(0.01 \mathrm{mg} / \mathrm{L})$, 
contamination greater than the 95th percentile value of less than 0.009 or less than $0.004 \mathrm{mg} / \mathrm{L}$, depending on the analytical method, could account for at least 90 percent or 40 percent of measured concentrations. Similarly, at the low end of the range of impairment risk for total phosphorus $(0.01 \mathrm{mg} / \mathrm{L})$, contamination greater than the 95 th percentile values of 0.0031 or $0.0076 \mathrm{mg} / \mathrm{L}$ could account for at least 31 or 76 percent, depending on the time period, of the concentrations that would indicate impairment.

\section{Pesticides}

Fourteen out of the 40 pesticides had at least 1 field-blank detection; metolachlor and atrazine had the highest frequency of detections with 1.7 and 1.8 percent, respectively (table 5). With 99-percent confidence, the percentage of detections for pesticide field blanks ranged from 0.7 to 3.4. The 99-percent UCL for percent detections in field blanks creates the lower bound for the detection frequency in environmental samples. For example, the detection frequency of metolachlor, adjusted for the frequency of contamination, is between 72 (75 minus 3.2 , rounded) and 75 percent, and that for atrazine is between 82 and 85 percent.

Minimal detection frequencies for all pesticides translate into high confidence that potential contamination bias is low. For the 38 pesticides with the fewest number of detections in field blanks, potential contamination is estimated, with 99-percent confidence, to be no greater than the detection limit in at least 98 percent of all samples (table 5). For metolachlor and atrazine, potential contamination is estimated, with 99-percent confidence, to be no greater than 0.0053 and $0.0093 \mu \mathrm{g} / \mathrm{L}$ in 98 percent of all samples and to be no greater than the detection limit in 97 percent of all samples.

Plots of the 99-percent UCL concentrations of field blanks (fig. 8) for the three pesticides with at least six detections plus selected others with several detections show that only 0.5 to 3 percent of environmental samples might be affected by contamination, as represented by the percentile extent of the red lines (absence of red lines indicate little likelihood of contamination of samples). In contrast to nutrients, potential contamination for pesticides is not limited to values in field blanks above the censor level. All quantified pesticide field blanks, whether above or below the censor level, are considered to reflect some contamination (as stated earlier, a pesticide result with zero contamination is presented by the NWQL as censored).

Human-health benchmarks (HHBs) consisting of EPA benchmarks and USGS health-based screening levels (Toccalino and others, 2014) and EPA aquatic-life benchmarks (U.S. Environmental Protection Agency, 2015b) provide a context for discussing conditions under which environmental data might need to be qualified because of potential contamination bias (table 7). Out of the 14 pesticides whose field blanks had at least 1 detection, 11 -simazine, prometon, deethylatrazine, metolachlor, diazinon, alachlor, acetochlor, trifluralin, EPTC, Dacthal, and cis-Permethrin—need no qualification because there is 99-percent confidence that the maximum potentially affected concentrations (table 7) of the respective environmental samples are less or far less than their respective HHB or aquatic-life benchmarks.

Because low concentrations of chlorpyrifos, atrazine, and dieldrin seen in environmental samples are within the range of some human-health or aquatic-life benchmarks (table 7), results for these pesticides need to be qualified in the context of comparing them with benchmarks. Although only a small percentage of environmental samples are potentially affected, estimates of contamination have high confidence. For chlorpyrifos, the EPA aquatic-life benchmark for chronic effects on invertebrates and the aquatic-life criterion continuous concentration for chronic effects on aquatic life, 0.04 and $0.041 \mu \mathrm{g} / \mathrm{L}$ (U.S. Environmental Protection Agency, 2015b; 2016d), respectively, are less than the maximum potentially affected concentration for chlorpyrifos of less than $0.05 \mu \mathrm{g} / \mathrm{L}$ (table 7). Contamination of chlorpyrifos is estimated, with 99-percent confidence, to be less than detection in at least 99.5 percent of all samples, and to exceed $0.005 \mu \mathrm{g} / \mathrm{L}$ in no more than 0.5 percent of all samples (absence of red line, fig. $8 A$ ). About 99.4 percent of reported concentrations in environmental samples (fig. $8 \mathrm{~A}$, orange dot on the environmental concentration curve) were less than the maximum potentially affected concentration of $0.05 \mu \mathrm{g} / \mathrm{L}$. Thus, contamination is likely to have affected no more than 0.5 percent of environmental samples, and only the 99.4 percent of those with concentrations less than $0.05 \mu \mathrm{g} / \mathrm{L}$, for a net potential effect on 0.5 percent of samples. For that small percentage potentially affected, contamination of chlorpyrifos could account for up to 13 or 12 percent of the concentrations in the chronic benchmark for invertebrates or the criterion continuous concentration for chronic effects on aquatic life, respectively.

The EPA aquatic-life benchmark for acute effects on nonvascular plants for atrazine is less than $1 \mu \mathrm{g} / \mathrm{L}$. Contamination of atrazine is estimated, with 99-percent confidence, to exceed $0.0093 \mu \mathrm{g} / \mathrm{L}$ in no more than 2 percent of all samples (table 5) and is less than detection $(0.004 \mu \mathrm{g} / \mathrm{L})$ in at least 97 percent of all samples (absence of red line, fig. 8D). About 67 percent of reported concentrations in environmental samples (fig. $8 D$, orange dot on the environmental concentration curve) were less than the maximum potentially affected concentration of $0.093 \mu \mathrm{g} / \mathrm{L}$ (table 7). Contamination is likely to have affected no more than 3 percent of the environmental samples (100 minus the 97 percent of field blanks that are not contaminated), and only the 67 percent of those with concentrations less than $0.093 \mu \mathrm{g} / \mathrm{L}$, for a net potential effect on no more than 2 percent of all samples. Therefore, contamination of atrazine could potentially account for the entire EPA aquatic-life benchmark for acute effects on nonvascular plants in no more than 2 percent of the samples. Because all HHBs and other aquatic-life benchmarks for atrazine are much higher than the potential contamination, comparisons of environmental sample results to any other benchmark need no qualification.

The USGS cancer health-based screening level of $0.002-0.2 \mu \mathrm{g} / \mathrm{L}$ for dieldrin (table 7 ) is a non-enforceable 
A. Chlorpyrifos

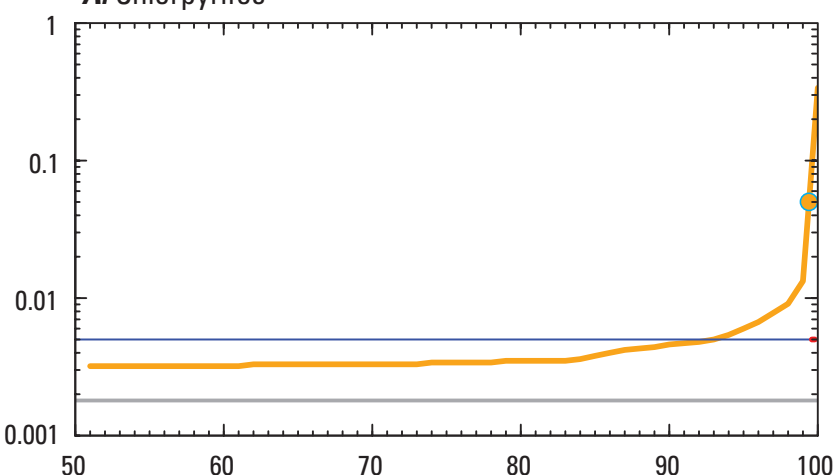

C. Metolachlor

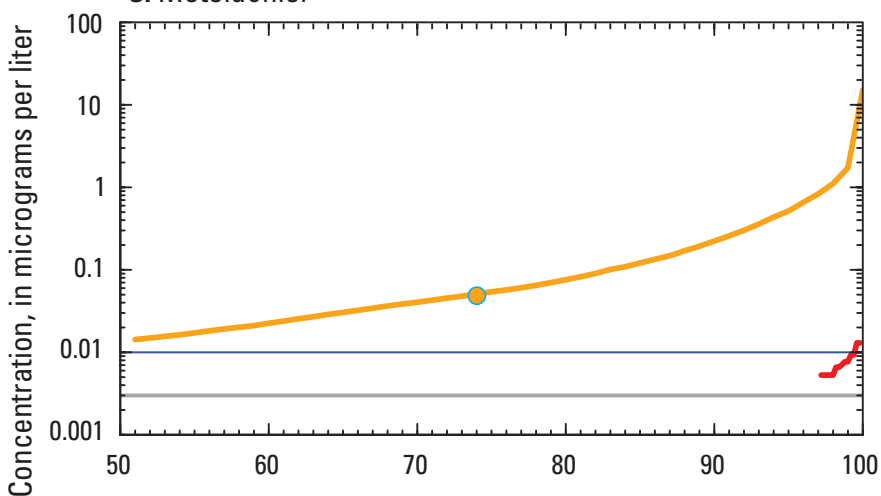

E. Trifluralin

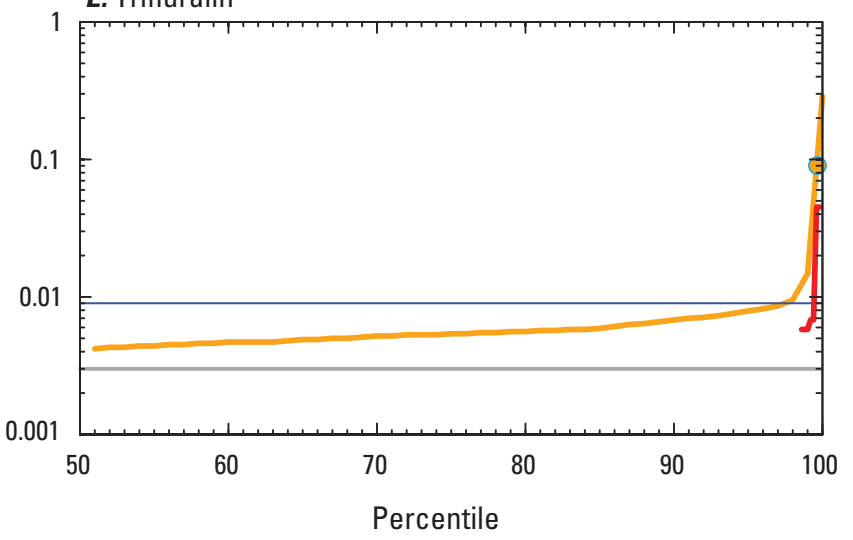

B. Dieldrin

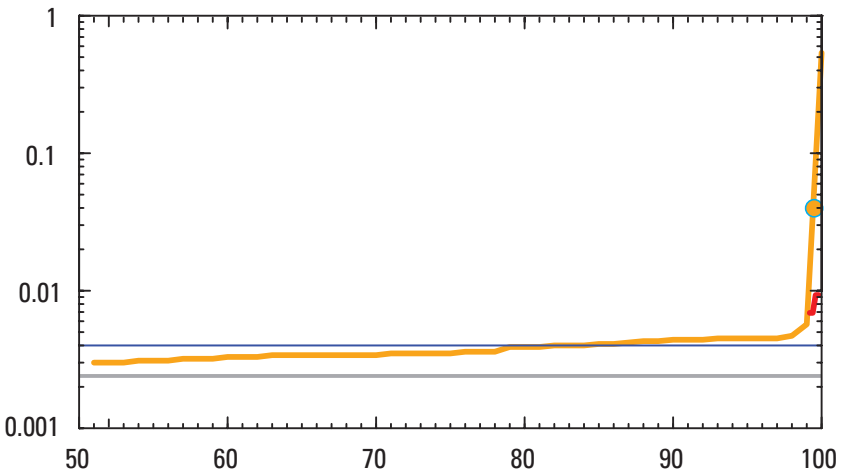

D. Atrazine

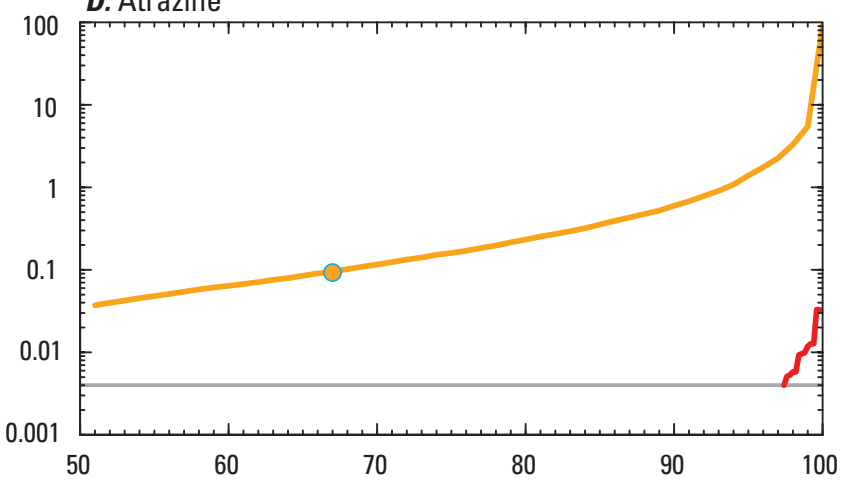

F. Dacthal

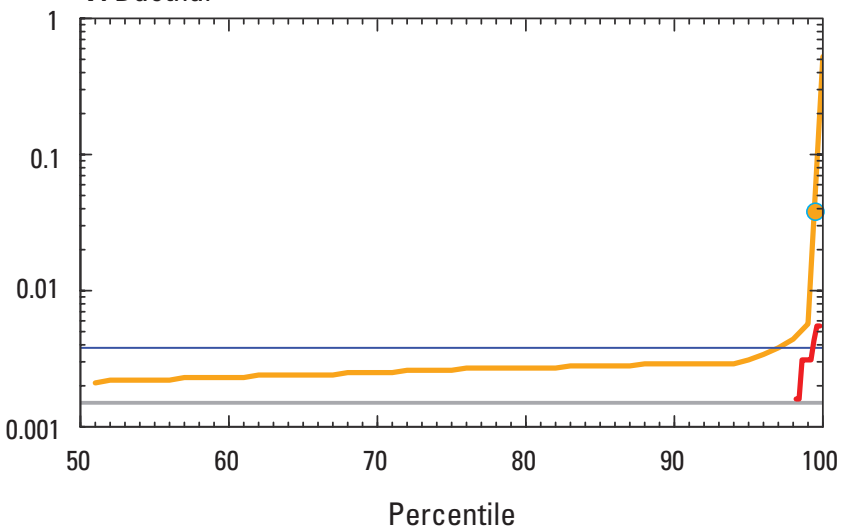

EXPLANATION

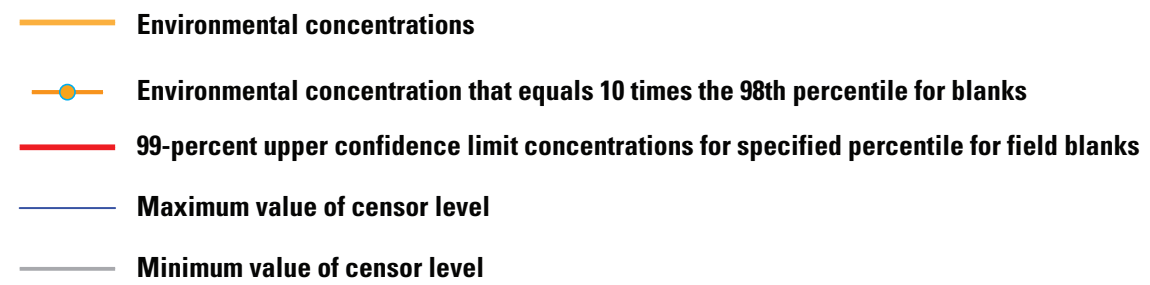

Figure 8. Distribution of concentrations of $A$, chlorpyrifos; $B$, dieldrin; $C$, metolachlor; $D$, atrazine; $E$, trifluralin; and $F$, Dacthal, in field blank and environmental surface-water samples from historical U.S. Geological Survey water-quality networks, water years $2002-12$. Nondetections are used to determine percentiles but are not shown on the graphs. 


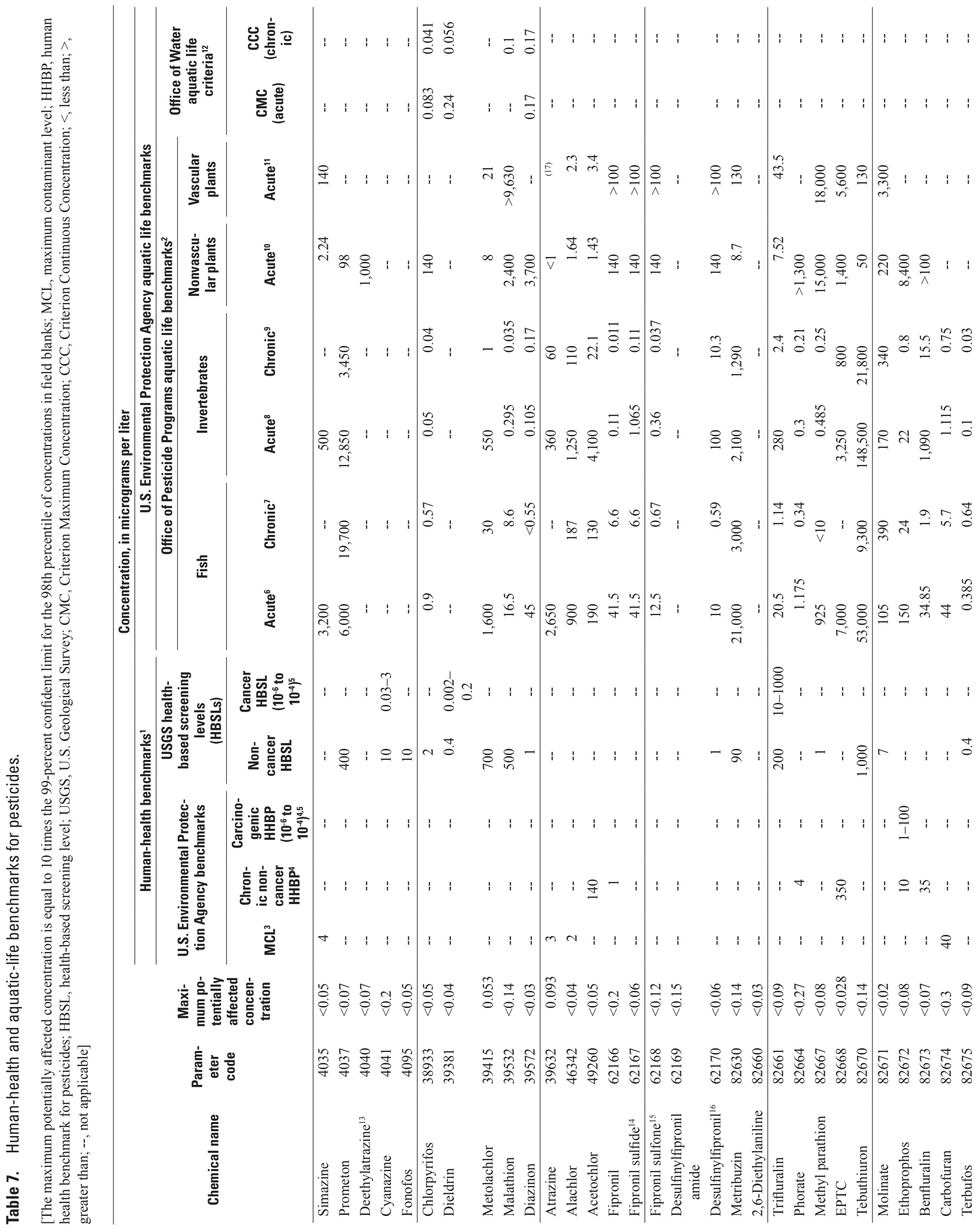




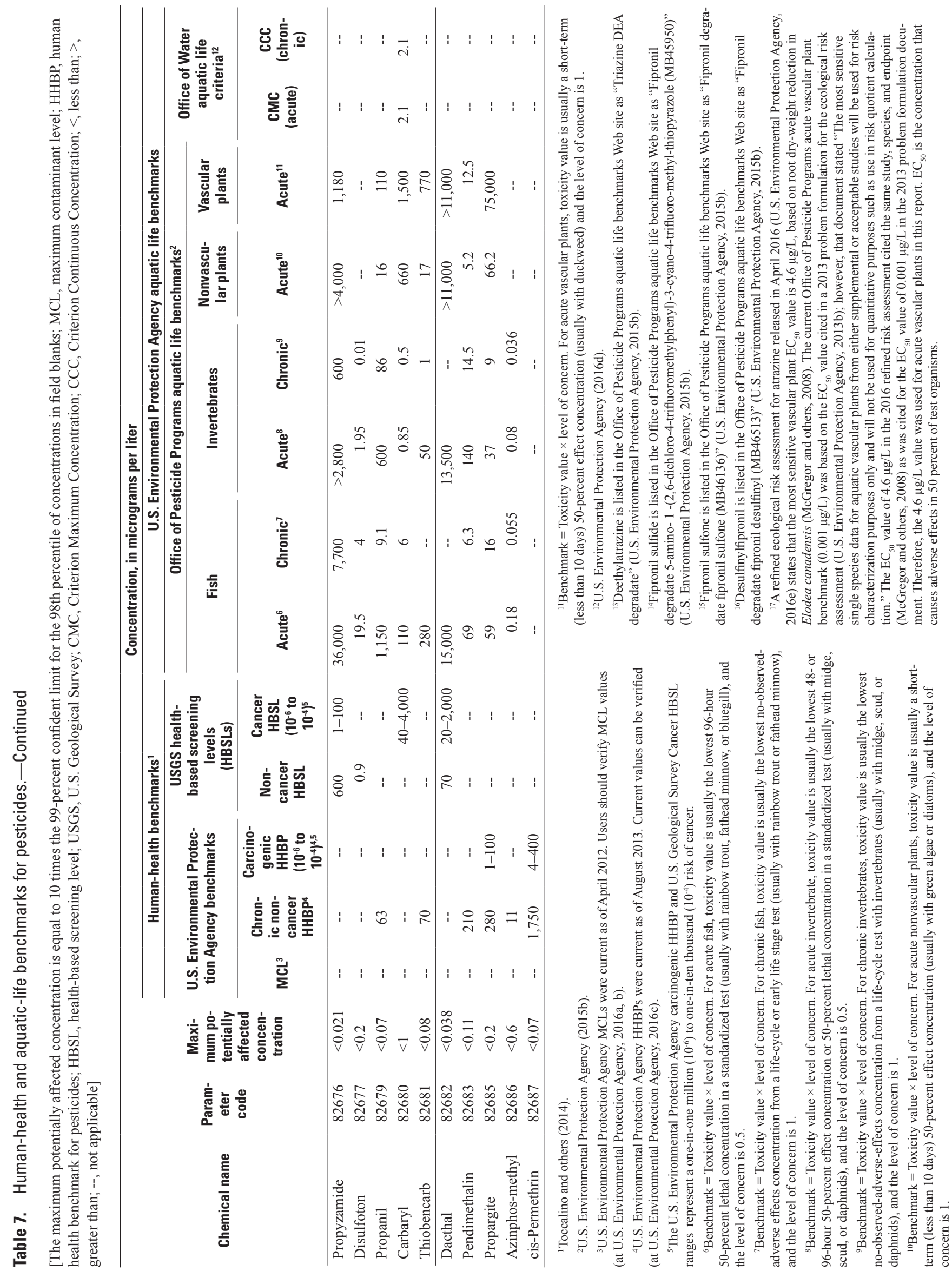


benchmark protective of cancer effects and represents a onein-one million to one-in-ten thousand cancer risk (Toccalino and others, 2014). In a calculation similar to that for atrazine, contamination of dieldrin is estimated, with 99-percent confidence, to be less than detection in at least 99 percent of all samples (absence of red line, fig. $8 B$ ). About 99.5 percent of reported concentrations in environmental samples (fig. $8 B$, orange dot on the environmental concentration curve) were less than the maximum potentially affected concentration of $0.04 \mu \mathrm{g} / \mathrm{L}$. Contamination is likely to have affected no more than 1 percent of environmental samples, the 99.5 percent of those with concentrations less than $0.04 \mu \mathrm{g} / \mathrm{L}$, for a net potential effect on 1 percent of all samples. When comparing dieldrin in environmental samples to the cancer health-based screening level, it is important to understand that contamination greater than the 99th percentile value of up to $0.004 \mu \mathrm{g} / \mathrm{L}$ could account for 2 to 100 percent of the concentrations within that benchmark range.

\section{Summary}

Potential contamination bias was estimated for 8 nutrient analytes and 40 pesticides in stream water collected at 147 sites in historical U.S. Geological Survey water-quality networks across the United States, representing a variety of hydrologic conditions and site types, for water years 2002-12. The majority of these sites are coincident with the current (2016) National Water Quality Network. Contamination is potentially introduced to water samples by exposure to airborne gases and particulates, from inadequate cleaning of sampling or analytic equipment, and from inadvertent sources during sample collection, field processing, shipment, and laboratory analysis. Potential contamination bias based on detections in field blanks is used to determine whether or under what conditions environmental data might need to be qualified for the interpretation of results in the context of comparisons with background levels, drinking-water standards, aquatic-life criteria or benchmarks, or human-health benchmarks. Environmental samples for which contamination bias as determined in this report applies are those from the aforementioned networks that were collected during the same time frame, according to the same protocols, and that were analyzed in the same laboratory as field blanks described in this report.

The finalized dataset of concentrations of nutrients and pesticides in field blanks associated with these surface-water samples has been screened for anomalous individual values, as well as patterns related to type of site, geography, sampling network, and, for pesticides only, by laboratory analytical schedule. Censored field-blank results presented in the report are recensored from the default laboratory reporting level to the long-term method detection level, the latter generally being half of the former.

Detection rates in field blanks for nutrients ranged from 4.3 percent for nitrite to 22 percent for particulate nitrogen.
Except for ammonia, dissolved species had the lowest percentage of detections, and totals had the highest. Consolidation of separate low- and standard-level methods of analysis for ammonia, nitrite, and orthophosphate into a single method in the second part of the report period resulted in increased detection rates that apparently related more to different analytical method choices than to differences over time in field-blank detections.

For samples analyzed with analytical method $\mathrm{SHC} 02$, which was used for all ammonia samples in the dataset of this report beginning in 2007, contamination potentially affecting 26.9 percent of environmental samples is estimated to exceed 0.0187 milligram per liter $(\mathrm{mg} / \mathrm{L})$ in no more than 5 percent and to exceed $0.0462 \mathrm{mg} / \mathrm{L}$ in no more than 1 percent of samples. Contamination could be higher than those values in the remaining 5 or 1 percent of all samples. About 2 percent of stream samples have the necessary combinations of high $\mathrm{pH}$ and high temperature to meet conditions within the range of the aquatic-life criteria for chronic effects for ammonia. Under the rare conditions found at the minimum of the range for chronic effects, contamination is likely to have affected no more than 0.5 percent of environmental samples analyzed with method SHC02 (or 0.1 or 0.2 percent of environmental samples analyzed with other methods); for that small set of samples, contamination could account for more than 23 to 25 percent of measured ammonia concentrations.

For nitrite, potential contamination is estimated to exceed $0.0011 \mathrm{mg} / \mathrm{L}$ in no more than 5 percent of environmental samples and to exceed $0.0034 \mathrm{mg} / \mathrm{L}$ in no more than 1 percent of samples analyzed with the most common method in use during the period (DZ001). Up to 3.3 percent of environmental samples analyzed by method DZ001, and between 0 and 2.6 percent of samples that used methods from the first part of the period, are potentially affected by nitrite contamination. For samples analyzed by the most commonly used method for nitrite plus nitrate (CL048), potential contamination is estimated to exceed $0.03 \mathrm{mg} / \mathrm{L}$ in no more than 5 percent of samples and to exceed $0.038 \mathrm{mg} / \mathrm{L}$ in no more than 1 percent of samples.

Although contamination potentially affects 21.2 percent of environmental samples analyzed for particulate nitrogen and 16.5 percent for total Kjeldahl nitrogen, the absence of drinking-water standards and aquatic-life criteria for these substances can allay concerns about contamination interfering with sample interpretation. Contamination from total nitrogen expected to exceed $0.064 \mathrm{mg} / \mathrm{L}$ in no more than 5 percent of samples and to exceed $0.441 \mathrm{mg} / \mathrm{L}$ in no more than 1 percent of samples potentially affects 1.1 percent of environmental samples.

Potential contamination from orthophosphate is estimated to exceed the respective censor levels for samples analyzed with three different methods in no more than 5 percent of all samples. For total phosphorus, potential contamination is expected to exceed 0.0031 and $0.0076 \mathrm{mg} / \mathrm{L}$, for samples analyzed with the most commonly used method CL021 and in 
the first and last parts of the period, respectively, in no more than 5 percent of all samples. Potential contamination is estimated to affect from 0 to 2 percent of environmental samples analyzed for orthophosphate and up to 5.5 or 6.3 percent of environmental samples analyzed for total phosphorus with method CL021 from the first and last parts of the period.

When comparing environmental samples to impairment risks for total nitrogen, orthophosphate, and total phosphorus, results should be qualified because contamination could account for a substantial fraction of the concentrations within the ranges of impairment risk, although only a small percentage of samples are likely to be affected by contamination. At the low end of the ranges for respective impairment risks, contamination greater than the 95 th percentile values could account for more than 23 percent (for total nitrogen), more than 40 or 90 percent (depending on the analytical method, for orthophosphate), or 31 or 76 percent (depending on the time period, for total phosphorus) of the concentrations that would indicate impairment. Similarly, for the nutrient analytes (ammonia, nitrite plus nitrate, total nitrogen, orthophosphate, and total phosphorus) with background concentrations discussed in the report, maximum concentrations potentially affected by contamination, for most analytical methods, are near or exceed the background concentrations. Conversely, maximum concentrations that might be affected by contamination do not exceed drinking-water standards for nitrite or for nitrite plus nitrate; thus these analytes require no qualification for comparisons with drinking-water standards.

Pesticide samples analyzed with NWQL schedule 2010, where extractions were done in the field rather than the laboratory, appear to show some contamination bias. Twenty-six pesticides had no detections in field blanks, and 4 pesticides had only 1 detection. Atrazine and metolachlor had the highest number of detections, 12 and 11, respectively. Estimates of detection frequencies of environmental samples adjusted for the 99-percent upper confidence limits for detection frequency in field blanks determined, for example, that metolachlor detections ranged from 72 to 75 percent and atrazine detections ranged from 82 to 85 percent.

The magnitude of contamination is estimated, with 99-percent confidence, to be no greater than the detection limit in at least 98 percent of environmental samples for 38 of the 40 pesticides covered in this report. For metolachlor and atrazine, potential contamination is no greater than 0.0053 and 0.0093 micrograms per liter in 98 percent of samples and is less than detection in 97 percent of environmental samples.

For 11 of 14 pesticides with at least 1 detection (simazine, prometon, deethylatrazine, metolachlor, diazinon, alachlor, acetochlor, trifluralin, EPTC, Dacthal, and cisPermethrin), there is 99-percent confidence that the maximum potentially affected concentration of environmental samples is less than their respective human-health or aquatic-life benchmark. Chlorpyrifos, dieldrin, and atrazine are the only pesticides with sufficient potential contamination to consider for the interpretation of results relative to human-health or aquatic-life benchmarks. Contamination from these three pesticides might affect no more than 0.5 percent of chlorpyrifos samples, 1 percent of dieldrin samples, or 2 percent of atrazine samples. Small percentages of environmental samples have concentrations high enough that chlorpyrifos contamination could account for 13 or 12 percent of the concentrations in the aquatic-life benchmarks for chronic effects on invertebrates or the criterion continuous concentration for chronic effects on aquatic life, respectively; that dieldrin contamination could account for up to 100 percent of the cancer health-based screening level for dieldrin; or that atrazine contamination potentially could account for the entire aquatic-life benchmark for acute effects on nonvascular plants.

\section{Acknowledgments}

We would like to thank all U.S. Geological Survey field personnel who collected and processed samples while diligently following established protocols. We thank staff at the National Water Quality Laboratory for tremendous proficiency and responsiveness to numerous questions. Thanks also to others who contributed to this report, notably Charles G. Crawford, Casey J. Lee, David K. Mueller, Julie Norman, David C. Reutter, Karen R. Ryberg, and Mark W. Sandstrom.

\section{References Cited}

Bender, D.A., Zogorski, J.S., Mueller, D.K., Rose, D.L., Martin, J.D., and Brenner, C.K., 2011, Quality of volatile organic compound data from groundwater and surface water for the National Water-Quality Assessment Program, October 1996-December 2008: U.S. Geological Survey Scientific Investigations Report 2011-5204, 128 p.

Bonn, B.A., 2008, Using the U.S. Geological Survey National Water Quality Laboratory LTMDL to evaluate and analyze data: U.S. Geological Survey Open-File Report 2008-1227, $73 \mathrm{p}$.

Childress, C.J.O., Foreman, W.T., Connor, B.F., and Maloney, T.J., 1999, New reporting procedures based on longterm method detection levels and some considerations for interpretations of water-quality data provided by the U.S. Geological Survey National Water Quality Laboratory: U.S. Geological Survey Open-File Report 99-193, 19 p.

DeSimone, L.A., 2009, Quality of water from domestic wells in principal aquifers of the United States, 1991-2004: U.S. Geological Survey Scientific Investigations Report 2008-5227, 139 p., accessed May 5, 2015, at http://pubs. usgs.gov/sir/2008/5227. 
Dubrovsky, N.M., Burow, K.R., Clark, G.M., Gronberg, J.M., Hamilton P.A., Hitt, K.J., Mueller, D.K., Munn, M.D., Nolan, B.T., Puckett, L.J., Rupert, M.G., Short, T.M., Spahr, N.E., Sprague, L.A., and Wilber, W.G., 2010, The quality of our Nation's waters-Nutrients in the Nation's streams and groundwater, 1992-2004: U.S. Geological Survey Circular $1350,174 \mathrm{p}$.

Fishman, M.J., ed., 1993, Methods of analysis by the U.S. Geological Survey National Water Quality LaboratoryDetermination of inorganic and organic constituents in water and fluvial sediments: U.S. Geological Survey OpenFile Report 93-125, 217 p.

Gilliom, R.J., Barbash, J.E., Crawford, C.G., Hamilton, P.A., Martin, J.D., Nakagaki, Naomi, Nowell, L.H., Scott, J.C., Stackelberg, P.E., Therlin, G.P., and Wolock, D.M., 2006, The quality of our Nation's waters-Pesticides in the Nation's streams and ground water, 1992-2001: U.S. Geological Survey Circular 1291, 172 p.

Hahn, G.J., and Meeker, W.Q., 1991, Statistical Intervals-A guide for practitioners: New York, John Wiley and Sons, 392 p.

Helsel, D.R., 2012, Statistics for censored environmental data using Minitab ${ }^{\circledR}$ and R (2d ed.): Hoboken, N.J., John Wiley and Sons, $324 \mathrm{p}$.

Helsel, D.R., and Hirsch, R.M., 2002, Statistical methods in water resources: U.S. Geological Survey Techniques of Water-Resources Investigations, book 4, chap. A3, 510 p. [Also available at http://pubs.usgs.gov/twri/twri4a3/.]

Madsen, J.E., Sandstrom, M.W., and Zaugg, S.D., 2003, Methods of analysis by the U.S. Geological Survey National Water Quality Laboratory_A method supplement for the determination of fipronil and degradates in water by gas chromatography/mass spectrometry: U.S. Geological Survey Open-File Report 02-462, 11 p., accessed July 22, 2015, at http://nwql.usgs.gov/Public/pubs/OFR02-462/ OFR02-462.html.

Martin, J.D., 1999, Quality of pesticide data for environmental water samples collected for the National Water-Quality Assessment Program, 1992-96 and examples of the use of quality-control information in water-quality assessments: U.S. Geological Survey, National Water-Quality Assessment Program, Pesticide National Synthesis Project Web page, accessed March 7, 2016, at http://water.usgs.gov/nawqa/ pnsp/pubs/qcsummary.html.

Martin, J.D., Eberle, Michael, and Nakagaki, Naomi, 2011, Sources and preparation of data for assessing trends in concentrations of pesticides in streams of the United States, 1992-2010: U.S. Geological Survey Data Series 655, 23 p., 5 apps.
Martin, J.D., Gilliom, R.J., and Schertz, T.L., 1999, Summary and evaluation of pesticides in field blanks collected for the National Water-Quality Assessment program, 1992-95: U.S. Geological Survey Open-File Report 98-412, 102 p.

McGregor, E.B., Solomon, K.R., and Hanson, M.L., 2008, Effects of planting system design on the toxicological sensitivity of Myriophyllum spicatum and Elodea canadensis to atrazine: Chemosphere, v. 73, p. 249-260.

Mueller, D.K., Martin, J.D., and Lopes, T.J., 1997, Qualitycontrol design for surface-water sampling in the National Water-Quality Assessment Program: U.S. Geological Survey Open-File Report 97-223, 17 p., accessed March 19, 2015, at http://pubs.usgs.gov/of/1997/223/.

Mueller, D.K., Schertz, T.L., Martin, J.D., and Sandstrom, M.W., 2015, Design, analysis, and interpretation of field quality-control data for water-sampling projects: U.S. Geological Survey Techniques and Methods, book 4, chap. C4, 54 p., accessed July 9, 2015, at http://dx.doi.org/10.3133/ tm4C4.

Mueller, D.K., and Titus, C.J., 2005, Quality of nutrient data from streams and ground water sampled during water years 1992-2001: U.S. Geological Survey Scientific Investigations Report 2005-5106, 27 p.

Patton, C.J., and Kryskalla, J.R., 2003, Methods of analysis by the U.S. Geological Survey National Water Quality Laboratory-Evaluation of alkaline persulfate digestion as an alternative to Kjeldahl digestion for determination of total and dissolved nitrogen and phosphorus in water: U.S. Geological Survey Water-Resources Investigations Report 03-4174, 33 p.

Patton, C.J., and Kryskalla, J.R., 2011, Colorimetric determination of nitrate plus nitrite in water by enzymatic reduction, automated discrete analyzer methods: U.S. Geological Survey Techniques and Methods, book 5, chap. B8, 34 p.

Patton, C.J., and Truitt, E.P., 1992, Methods of analysis by the U.S. Geological Survey National Water Quality Laboratory-Determination of total phosphorus by a Kjeldahl digestion method and an automated colorimetric finish that includes dialysis: U.S. Geological Survey Open-File Report 92-146, 39 p., accessed January 19, 2016, at http://nwql. usgs.gov/Public/pubs/OFR92-146/OFR92-146.html.

Patton, C.J., and Truitt, E.P., 2000, Methods of analysis by the U.S. Geological Survey National Water Quality Laboratory-Determination of ammonium plus organic nitrogen by a Kjeldahl digestion method and an automated photometric finish that includes digest cleanup by gas diffusion: U.S. Geological Survey Open-File Report 00-170, 31 p., accessed July 19, 2016, at http://nwql.usgs.gov/Public/pubs/ OFR00-170/OFR00-170.html. 
Rus, D.L., Patton, C.J., Mueller, D.K., and Crawford, C.G., 2012, Assessing total nitrogen in surface-water samplesPrecision and bias of analytical and computational methods: U.S. Geological Survey Scientific Investigations Report 2012-5281, 38 p.

Sprague, L.A., Harned, D.A., Hall, D.W., Nowell, L.H., Bauch, N.J., and Richards, K.D., 2007, Response of stream chemistry during base flow to gradients of urbanization in selected locations across the conterminous United States, 2002-04: U.S. Geological Survey Scientific Investigations Report 2007-5083, 133 p.

Toccalino, P.L., Norman, J.E., and Hitt, K.J., 2010, Quality of source water from public-supply wells in the United States, 1993-2007: U.S. Geological Survey Scientific Investigations Report 2010-5024, 206 p.

Toccalino, P.L., Norman, J.E., and Schoephoester, K.M., 2014, Health-based screening levels for evaluating water-quality data: U.S. Geological Survey database, accessed August 31, 2015, at http://dx.doi.org/10.5066/F71C1TWP.

U.S. Environmental Protection Agency, 1993, Method 365.1-Determination of phosphorus by semi-automated colorimetry: U.S. Environmental Protection Agency, EPA/600/R-93/100, 17 p.

U.S. Environmental Protection Agency, 1997, Definition and procedures for the determination of the method detection limit, appendix B, part 136 of Guidelines establishing test procedures for the analysis of pollutants: U.S. Code of Federal Regulations, Title 40, revised July 1, 1997, p. 265-267.

U.S. Environmental Protection Agency, 2000, Nutrient criteria technical guidance manual-Rivers and streams: U.S. Environmental Protection Agency, EPA-822-B-00-002, 152 p., 4 apps.

U.S. Environmental Protection Agency, 2009, National primary drinking water regulations: U.S. Environmental Protection Agency, EPA 816-F-09-004, 6 p.

U.S. Environmental Protection Agency, 2013a, Aquatic life ambient water quality criteria for ammonia-Freshwater-2013: U.S. Environmental Protection Agency, EPA822-R-13-001, 242 p.

U.S. Environmental Protection Agency, 2013b, Addendum to the Problem Formulation for the Ecological Risk Assessment to be conducted for the Registration Review of Atrazine: U.S. Environmental Protection Agency, Office of Pesticide Programs, 227 p., accessed June 29, 2016, at https://www.regulations.gov/document?D=EPA-HQOPP-2013-0266-0002.

U.S. Environmental Protection Agency, 2015a, Preventing eutrophication-Scientific support for dual nutrient criteria: U.S. Environmental Protection Agency, EPA820-S-15-001, 6 p.
U.S. Environmental Protection Agency, 2015b, Office of Pesticide Programs' aquatic life benchmarks: U.S. Environmental Protection Agency Office of Pesticide Programs Web page, accessed June 27, 2016, at https://www.epa.gov/ pesticide-science-and-assessing-pesticide-risks/aquatic-lifebenchmarks-pesticide-registration.

U.S. Environmental Protection Agency, 2016a, Drinking water contaminant human health effects information: U.S. Environmental Protection Agency Web page, accessed June 8, 2016, at http://water.epa.gov/drink/contaminants/index. cfm-mcls.

U.S. Environmental Protection Agency, 2016b, Drinking water contaminants - Standards and regulations: U.S. Environmental Protection Agency Web page, accessed June 8, 2016, at http://water.epa.gov/drink/standards/hascience.cfm.

U.S. Environmental Protection Agency, 2016c, Human health benchmarks for pesticides: U.S. Environmental Protection Agency Web page, accessed June 8, 2016, at https://iaspub. epa.gov/apex/pesticides/f?p=HHBP:home.

U.S. Environmental Protection Agency, 2016d, National recommended water quality criteria-Aquatic life criteria table: U.S. Environmental Protection Agency Web site, accessed June 29, 2016, at https://www.epa.gov/wqc/ national-recommended-water-quality-criteria-aquatic-lifecriteria-table.

U.S. Environmental Protection Agency, 2016e, Refined ecological risk assessment for atrazine: U.S. Environmental Protection Agency report EPA-HQ-OPP-2013-0266, accessed June 29, 2016, at https://www.regulations.gov/ document?D=EPA-HQ-OPP-2013-0266-0315.

U.S. Geological Survey, variously dated, National field manual for the collection of water-quality data: U.S. Geological Survey Techniques of Water-Resources Investigations, book 9, chaps. A1-A9, accessed January 22, 2016, at http:// pubs.water.usgs.gov/twri9A.

Zaugg, S.D., Sandstrom, M.W., Smith, S.G., and Fehlberg, K.M., 1995, Methods of analysis by the U.S. Geological Survey National Water Quality Laboratory-Determination of pesticides in water by $\mathrm{C}-18$ solid-phase extraction and capillary-column gas chromatography/mass spectrometry with selected-ion monitoring: U.S. Geological Survey Open-File Report 95-181, 49 p., accessed July 22, 2015, at http://wwwnwql.cr.usgs.gov/Public/pubs/OFR95-181/ OFR95-181.html.

Zimmerman, C.F., Keefe, C.W., and Bashe, Jerry, 1997, Method 440.0 Determination of carbon and nitrogen in sediments and particulates of estuarine/coastal waters using elemental analysis: U.S. Environmental Protection Agency, EPA/600/R-15/009, 10 . 



\section{Glossary of Data-Quality Terms}

Accuracy The degree of agreement between a measured value and the true or expected value. Accuracy is affected by both bias and variability.

Bias The systematic error inherent in a method; it can be either positive or negative.

Blank sample A sample prepared from water that is free of the analyte(s) of interest for determining contamination.

Contamination bias A positive bias due to the inadvertent introduction of analytes into water samples during sample collection, processing, shipment, or analysis.

Field blank A blank sample that has been exposed in the field to all sampling equipment and conditions that normally are associated with the collection of an environmental sample.

Quality assessment The overall process of assessing the quality of environmental data by reviewing the application of the qualityassurance elements and the analysis of the quality-control data.

Quality assurance (OA) Procedures used to control the nonquantifiable components of a project, such as sampling at the correct location with the proper equipment and using the appropriate methods.

Quality control (QC) Data generated to estimate the magnitude of the bias and variability in the process of obtaining environmental data.

Precision The degree of mutual agreement among independent measurements from the repeated application of a measurement process under identical conditions. Precision is the inverse of variability.

Variability Random error in independent measurements as the result of repeated application of the measurement process under identical conditions. 


\section{Appendixes}

The appendixes consist of two tables of field-blank data, one for nutrients (appendix 1) and one for pesticides (appendix 2). In each appendix file, the metadata (first tab) defines column headings in the data table (second tab). Data tables are formatted as one result per row, with elements of station identification number, date, parameter name (pesticides only), parameter code, method (nutrients only), schedule (pesticides only), remark, result, flag, recensor note (with information specific to recensoring, such as "LRL 0.006 recensor to LTMDL of 0.003 ”), and comment.
Where ancillary codes for samples have been changed from those stored in the permanent U.S. Geological Survey (USGS) National Water Information System (NWIS; the national repository of USGS water data), comments are provided in appendixes 1 and 2. Flag and comment fields are provided for applicable records in appendixes 1 and 2 to indicate suggested use of the data: for instance, flag $=1$ indicates no restrictions on data use; flag $=2$ indicates an alert but no suggestion to disregard the data; and flag $=3$ indicates a suggestion to disregard the data. The comment field is used to explain assignments of flags 2 or 3 . Information in NWIS has not been changed.

\section{Appendix 1. Nutrient Field-Blank Data From Surface-Water Sites in Historical U.S. Geological Survey Water-Quality Networks, 2002-12.}

[Available for download at http://dx.doi.org/10.3133/sir20165129.]

\section{Appendix 2. Pesticide Field-Blank Data From Surface-Water Sites in Historical U.S. Geological Survey Water-Quality Networks, 2002-12.}

[Available for download at http://dx.doi.org/10.3133/sir20165129.] 
For more information concerning this report, contact: Director, New England Water Science Center

U.S. Geological Survey

331 Commerce Way, Suite 2

Pembroke, NH 03275

dc_nweng@usgs.gov

or visit our Web site at:

http://newengland.water.usgs.gov

Publishing support by:

The Pembroke, Rolla, and West Trenton Publishing Service Centers 


\section{$\frac{\mathbb{2}}{3}$}

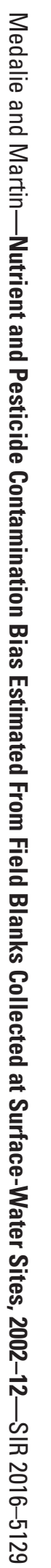

